\title{
Molecular targets in urothelial cancer: detection, treatment, and animal models of bladder cancer
}

This article was published in the following Dove Press journal:

Drug Design, Development and Therapy

5 October 2016

Number of times this article has been viewed

\author{
Dmitriy Smolensky ${ }^{1,2}$ \\ Kusum Rathore' \\ Maria Cekanova ${ }^{1,2}$ \\ 'Department of Small Animal Clinical \\ Sciences, College of Veterinary \\ Medicine, ${ }^{2}$ UT-ORNL Graduate School \\ of Genome Science and Technology, \\ The University of Tennessee, \\ Knoxville, TN, USA
}

\begin{abstract}
Bladder cancer remains one of the most expensive cancers to treat in the United States due to the length of required treatment and degree of recurrence. In order to treat bladder cancer more effectively, targeted therapies are being investigated. In order to use targeted therapy in a patient, it is important to provide a genetic background of the patient. Recent advances in genome sequencing, as well as transcriptome analysis, have identified major pathway components altered in bladder cancer. The purpose of this review is to provide a broad background on bladder cancer, including its causes, diagnosis, stages, treatments, animal models, as well as signaling pathways in bladder cancer. The major focus is given to the $\mathrm{PI} 3 \mathrm{~K} / \mathrm{AKT}$ pathway, p53/pRb signaling pathways, and the histone modification machinery. Because several promising immunological therapies are also emerging in the treatment of bladder cancer, focus is also given on general activation of the immune system for the treatment of bladder cancer.
\end{abstract}

Keywords: bladder cancer, transitional cell carcinoma, signaling pathways, clinical trials

\section{Introduction}

Bladder cancer is the fifth most common cancer in the United States and accounts for $4.5 \%$ of all new cancer cases. ${ }^{1}$ In 2016 , an estimated 76,960 new patients will be diagnosed with bladder cancer, whereas 16,390 will die from complications of this disease. ${ }^{2}$ Bladder cancer is the fourth most common cancer diagnosed in males and is three times less common in females. ${ }^{3}$ The most common type of bladder cancer is transitional cell carcinoma (TCC), also known as urothelial cancer, and accounts for $>90 \%$ of all bladder cancer cases in the United States. ${ }^{4-6}$ Transitional cells are specialized epithelial cells that line the inside of the bladder and some other organs; unlike normal epithelial cells, transitional cells can contract or expand. Less common types of bladder cancer include squamous cell carcinoma and adenocarcinoma. ${ }^{7}$ Even rarer are sarcomas, which account for $<1 \%$ of bladder cancers; sarcomas do not arise from the urothelial layer but from the stroma layers of the bladder. ${ }^{8}$ Because of the rarity of other types of bladder cancers, TCC is the most studied of the bladder cancers and is the focus of this review.

This review summarizes the risk factors for developing bladder TCC, molecular markers for diagnosis, and personalized targeted therapies of TCC and the outcomes of current clinical trials and studies using animal models to advance knowledge in managing bladder cancer.

\section{Risk factors}

The nonenvironmental risk factors for bladder cancer include age, sex, ethnicity, body weight, lifestyle, and familial history. With increasing age, the risk of developing 
bladder cancer increases. Currently, the median age of patients diagnosed with TCC is between 65 years and 70 years. $^{9}$ For unknown reasons, bladder cancer is three to four times more likely to occur in men than in women. ${ }^{6}$ While the exact mechanism to account for the difference in risk of developing TCC as it relates to sex is unknown, in a study using a nude mice transplant model, it was determined that bladders of mice injected with male androgen hormones progress more often to carcinogenesis than bladders of mice treated with female estrogenic compounds. ${ }^{9,10}$ While race seems to be a contributing factor in the male population, with white males having twice the incidence of Asian, black, or Hispanic males, the difference in incidence due to race in females is far less pronounced. ${ }^{9}$ One interesting finding in the difference between black and white males who develop bladder cancer is that white males in the United States are more likely to develop noninvasive bladder cancer, whereas black males are more likely to develop invasive bladder cancer, leading to a worse survival rate in the black male population..$^{9,11,12}$

Lifestyle choices linked to cancer risks have been documented in many studies, and there is overwhelming evidence that obesity, poor diet, and physical inactivity are linked to increased risk of developing several types of cancers. ${ }^{13}$ A strong correlation exists between obesity and an increased risk for development of bladder cancer. ${ }^{14}$ It was recently shown that the combination of smoking and obesity not only increased the risk of developing bladder cancer, but also significantly increased the risk of bladder cancer recurrence and mortality of patients who were already successfully treated for noninvasive bladder cancer. ${ }^{15}$ Because many toxins are expelled through excretion via the urinary system, those toxins can accumulate in the bladder and promote the initiation of bladder cancer. In addition, poor quality of drinking water with contaminants and/or additives has been linked to bladder cancer risk factors. The long-term consumption of chlorinated drinking water containing a complex mixture of chlorinated and brominated byproducts with mutagenic and carcinogenic properties was associated with bladder cancer with a combined risk estimate of 1.4 for men on the basis of five studies and 1.2 for women on the basis of five studies as reviewed in the study of Villanueva et al. ${ }^{16}$ In addition, previous studies demonstrated that high levels of arsenic in drinking water are associated with excess cancer risk factors for bladder cancer. ${ }^{17,18}$ According to the US Environmental Protection Agency, the maximum contaminant level of arsenic in drinking water is $10 \mu \mathrm{g} / \mathrm{L}$, which has been associated with bladder cancer risk. ${ }^{19}$ Some of the major environmental factors of developing TCC include use of tobacco products, occupational carcinogens (eg, arsenic), and prior chemotherapeutic drug exposure. Tobacco use is perhaps the best documented risk factor for developing TCC. ${ }^{20}$ A recent study has shown that cigarette smoking accounts for $>50 \%$ of all bladder cancer diagnoses in the United States. ${ }^{21}$ Cessation of smoking reduces the risk of recurrence of bladder cancer even if the initial diagnosis occurred while the patient was an active smoker. ${ }^{22}$ These findings suggest that the continuation of smoking increases the risk of bladder cancer recurrence.

There are many occupational hazards that increase the risk of developing bladder TCC as well. These risk factors include, but are not limited to, exposure to diesel exhaust, polycyclic aromatic hydrocarbons, and certain pesticides and herbicides. ${ }^{23-25}$ It has been reported that patients treated with cyclophosphamide (Cytoxan) can develop renal or bladder cancer as one of the possible adverse events of chemotherapy. ${ }^{20,26}$ Therefore, lifestyle intervention would greatly benefit prevention and management, as well as decrease recurrence of bladder cancer.

While familial bladder cancer seems to be rare, it has been determined that the risk of developing bladder cancer increases two-fold when another close family member has already been diagnosed with bladder cancer. ${ }^{20}$ It has been suggested that familial mutations of the $\mathrm{pRb}$ may contribute to the risk of developing bladder cancer. ${ }^{27}$ The $\mathrm{p} 53 / \mathrm{pRb}$ pathway is also often altered in bladder cancer and will be covered in detail in the "Molecular targets" section. In addition, some evidence suggests that individuals, especially smokers with genetically overactive CYP1A2, may be at greater risk for developing bladder cancer. ${ }^{28}$ Specific mutations in the CYP1A2 gene can be activated by carcinogens present in cigarette smoke, including 4-aminobiphenyl, which can form DNA adducts and cause mutations of other genes..$^{28,29}$

\section{Diagnosis and staging}

The most common signs and symptoms of bladder cancer include blood in the urine and pain during urination. ${ }^{6}$ Several invasive and noninvasive techniques exist to diagnose bladder cancer. One of the primary noninvasive techniques is urine cytology evaluation, in which cells that are shed can be observed for any abnormalities or malignancies. ${ }^{30}$ A urine culture may be inoculated in order to differentiate the diagnosis from an infection. ${ }^{30}$ While a positive result from urine cytology test for presence of cancer cells can be used as a diagnosis, a negative result does not always indicate absence of cancer. ${ }^{30}$ The urine sample can be used 
for detection of bladder cancer biomarkers. One of the most common biomarker tests is the bladder tumor antigen test; however, the test's specificity and sensitivity can vary greatly, with a high incidence of false positives. ${ }^{31}$ Several biomarkers that are used in combination to diagnose bladder cancer are reviewed by Tilki et al. ${ }^{31}$

Cystoscopy followed by biopsy is the gold standard for diagnosis of bladder cancer. ${ }^{30}$ Currently, two forms of cystoscopy are available: white light cystoscopy and fluorescence cystoscopy. While papillary tumors can almost always be seen using white light cystoscopy, it becomes much more difficult to detect carcinoma in situ using white light cystoscopy alone. In a study by Fradet et al, ${ }^{32}$ only $62 \%$ of tumors were detected during white light cystoscopy; however, 92\% of carcinomas in situ were detected when fluorescent cystoscopy was applied. The ability to differentiate tumor tissues from surrounding normal tissues using targeted fluorescence imaging will help to improve diagnosis, as well as outcome of image-guided surgeries in patients diagnosed with bladder cancer. Nontargeted fluorescent imaging agents, such as hexaminolevulinate and 5-aminolevulinic acid, accumulate in cancer tissue, providing an increased signal when compared with normal epithelium. Additionally, porphyrins emit red light when excited with blue light for detection. ${ }^{33}$ Fluorescence cystoscopy detects up to $15 \%$ more tumors than white light cystoscopy. Patients diagnosed to be positive via urine cytology tests but negative via white light cystoscopy are excellent candidates for fluorescence cystoscopy. ${ }^{33-35}$ Targeting specific markers that are overexpressed in tumors by imaging agents is a key strategy for detection of tumor versus normal tissue. Development and synthesis of new imaging agents that specifically target tumor tissue are currently under intensive investigation (reviewed by Kim et $\mathrm{al}^{36}$ and
deBoer et $\mathrm{al}^{37}$ ). One example of such an agent is fluorocoxib A, a novel derivative of indomethacin that specifically binds to cyclooxygenase-2 (COX-2)-expressing bladder cancers. ${ }^{38-40}$ Fluorocoxib A has shown promise in detection of bladder TCC using mouse and canine bladder cancer models. ${ }^{39}$

Other imaging modalities used for the diagnosis of bladder cancers are computed tomography (CT), magnetic resonance imaging, and ultrasound. ${ }^{41} \mathrm{CT}$ has been successful in imaging of bladder cancer and has advantages of being less invasive than cystoscopy. While sensitivity of CT was found to be as high as $95 \%-99 \%$, it fell short in specificity ( $~ 83 \%)$, with false positive results in detection of bladder cancer. ${ }^{42}$ A combination of $\mathrm{CT}$ with cystoscopy improves diagnosis of bladder cancer to $100 \%$ with $94 \%$ specificity. ${ }^{42}$ Magnetic resonance imaging, while not often used for diagnosis of bladder cancer, is an excellent imaging method to stage bladder cancer. ${ }^{43}$ Staging accuracy for differentiation between invasive and superficial bladder cancers was improved to $85 \%$. ${ }^{44}$ Sensitivity of ultrasound is $\sim 72 \%$ and that can be further improved by contrast-enhanced ultrasound with a sensitivity of $88 \%$; however, detection of tumors $<5 \mathrm{~mm}$ diameter is only $20 \%$. $^{45}$

After cystoscopy, the obtained biopsy sample is histologically evaluated for confirmation, grading, and staging of bladder cancer. ${ }^{46}$ The classic tumor/node/metastasis (TNM) staging method (Table 1$)^{9,47}$ involves evaluating the condition of the tumor and if it has invaded surrounding tissue (T), lymph node involvement $(\mathrm{N})$, and metastasis $(\mathrm{M}) .{ }^{47}$ When the tumor is present on the epithelial layer and has not breached the basement membrane into the surrounding muscle tissue, it is referred to as a noninvasive superficial tumor or carcinoma in situ. ${ }^{6,48}$ When tumor cells breach the basement membrane and invade the muscle tissue

Table I Clinical staging of bladder cancer

\begin{tabular}{|c|c|c|c|}
\hline Stage & Tumor (T) & Lymph node involvement $(\mathrm{N})$ & Metastasis (M) \\
\hline Stage $0 \mathrm{a}$ & Ta: noninvasive papillary carcinoma & No & Mo \\
\hline Stage Ois & Tis: carcinoma in situ & No & Mo \\
\hline Stage I & $\mathrm{TI}$ : has grown into connective tissue & No & Mo \\
\hline \multirow[t]{2}{*}{ Stage II } & T2a: has grown into inner half of muscle layer & No & Mo \\
\hline & T2b: has grown into outer half of muscle layer & No & Mo \\
\hline \multirow[t]{2}{*}{ Stage III } & T3a: microscopic invasion of surrounding fatty tissue & No & Mo \\
\hline & $\begin{array}{l}\text { T3b: macroscopically detectable invasion of } \\
\text { surrounding fatty tissue }\end{array}$ & No & Mo \\
\hline \multirow[t]{4}{*}{ Stage IV } & T4a: spread into prostate (men) and uterus (women) & No & Mo \\
\hline & T4b: has grown into pelvic or abdominal wall & No & Mo \\
\hline & Any $T$ & $\begin{array}{l}\mathrm{NI}-3 \text { : lymph node involvement in } \\
\text { proximal or distal lymph nodes }\end{array}$ & Mo \\
\hline & Any $T$ & Any $\mathrm{N}$ : any lymph node involvement & MI: metastasis present \\
\hline
\end{tabular}

Notes: According to American Joint Committee on Cancer (AJCC). N0, no lymph node involvement; M0, No signs of metastasis. 
surrounding the bladder and other organs, it is referred to as invasive $\mathrm{TCC}^{6,49}$ and is associated with a poor prognosis. ${ }^{6}$ While the 5-year survival rate of patients diagnosed with the early stages of bladder cancer is $69.2 \%$, the survival rate drops drastically to only $5.5 \%$ for patients diagnosed with metastatic bladder cancer. ${ }^{50}$

\section{Current treatment options}

Treatment of bladder cancer depends on the level of invasion and metastasis of the tumor and is divided into two distinct categories: superficial and invasive bladder cancers.

Superficial bladder cancer is well managed by transurethral resection, followed by intravenous or intravesical (directly into the bladder) administration of chemotherapeutic drugs, such as mitomycin, epirubicin, or doxorubicin. ${ }^{51-53}$ This combination therapy is extremely important due to the high rates of bladder cancer recurrence. ${ }^{6}$ The intravesical injection of bacillus Calmette-Guérin (BCG), as adjuvant immunotherapy, activates the immune system in the patient and greatly increases progression-free survival rates. ${ }^{53,54}$ For noninvasive bladder cancer, BCG has been shown to be more effective than chemotherapy in preventing bladder cancer recurrence. ${ }^{55,56}$ Management and treatment of patients with muscle invasive bladder cancer are usually a radical cystectomy (removal of whole bladder) and possibly removal of surrounding organs, such as lymph nodes; prostate and seminal vesicles in men; and the uterus, ovaries, and part of the vagina in women. ${ }^{6}$ Radical cystectomy is usually followed by adjuvant therapy, such as chemotherapy and radiation therapy. Chemotherapy protocols without radiation include several options, such as cisplatin alone, cisplatin with 5-fluorouracil, and mitomycin with 5-fluorouracil. ${ }^{57}$ Chemotherapy protocols in conjunction with radiation include gemcitabine with cisplatin; the MVAC protocol, which includes methotrexate, vinblastine, doxorubicin (adriamycin), and cisplatin; or a combination of carboplatin with either paclitaxel or docetaxel. ${ }^{57}$ Recently, Kanatani et $\mathrm{al}^{58}$ have shown that cisplatin-based adjuvant therapy, including MVAC, greatly increases median survival time in patients with node-positive bladder cancer, while increasing body mass index. On the other hand, cisplatin-based therapy had poor tolerance, and the dose must be lowered for many patients who experienced side effects. ${ }^{58}$ Because side effects of chemotherapy can be intolerable for some patients, research is focused on development of targeted therapies that have fewer side effects. More information on treatment options of bladder cancer can be found in a review by Carballido and Rosenberg. ${ }^{59}$

\section{Molecular targets}

In order to develop proper targeted therapy for any cancer, the molecular targets that drive the cancers need to be well understood. Like other types of cancers, bladder cancer development is a multistage process beginning with initiation, promotion, and progression. ${ }^{60,61}$ In colorectal cancer progression, the loss of tumor suppressor APC is common in the early stages of cancer (initiation/promotion), whereas the loss of tumor suppressor BRCA1 or BRCA2 is common in breast cancers. ${ }^{62,63}$ The multistage process of carcinogenesis is not different in bladder cancer, but has its own unique pathways/genes that are commonly altered. ${ }^{64-66}$ In 2014, the Genome Atlas Research Network (the Cancer Genome Atlas, TCGA) published a study that not only outlined genome, transcriptome, and mutational data but also correlated many molecular events with specific stages and prognosis of patients in 131 urothelial carcinomas. ${ }^{65}$

\section{$p 53$ and pRb pathways in regulation of bladder cancer cell cycle}

As the cell undergoes stress with induction of DNA damage, the p53 protein is activated and localizes to the nucleus, where it functions as a transcription factor. The p53 protein controls cell cycle arrest genes, such as p21 and p16, as well as proapoptotic proteins, such as Bax. ${ }^{67}$ The p21 and p16 proteins are cyclin-dependent kinase inhibitors that prevent the downstream phosphorylation of $\mathrm{pRb}$. The unphosphorylated $\mathrm{pRb}$ inhibits progression from the G1 to $\mathrm{S}$ phase of the cell cycle. ${ }^{68}$ The p53 protein is a tumor suppressor, and the gene coding for $p 53$ is mutated in $>50 \%$ of all cancers. ${ }^{69}$ The p53 pathway is disrupted in invasive bladder cancer and has been correlated with poor clinical outcome, progression to invasive from noninvasive bladder cancer, and resistance to radiation therapy. ${ }^{70-73}$ The TCGA network found that the $\mathrm{p} 53 / \mathrm{pRb}$ pathway is altered in $93 \%$ of patients whose genome was sequenced. ${ }^{65}$ In many aggressive bladder cancers, the p53 gene is mutated, overexpressed, and highly localized to the nucleus, where it is rapidly degraded. ${ }^{70}$ Further progression indicates loss of function of $\mathrm{pRb}$ and loss of expression of tumor suppressor genes $\mathrm{p} 21$ and $\mathrm{p} 16 .^{73,74}$ While $\mathrm{p} 16$ and $\mathrm{p} 21$ are within the $\mathrm{p} 53$ pathway, their expression can be dependent or independent of $p 53 .^{73,75}$ The most interesting feature of this pathway in bladder cancer is that loss of function of expression of $\mathrm{p} 53$, $\mathrm{p} 21, \mathrm{pRb}$, and $\mathrm{p} 16$ proteins appears to have an additive negative prognostic effect, suggesting that more than one linear pathway is responsible. ${ }^{73}$ Other pathway genes that 
underwent alterations include ataxia telangiectasia mutated (activator of p53), MDM2 (inhibitor of p53), EF2A (target of pRb), and FBXW7 (ubiquitin kinase of cyclin E). ${ }^{65}$

While the alterations in the $\mathrm{p} 53 / \mathrm{pRb}$ pathway have been clearly characterized, new sequencing data reveal other possible drug targets. For example, a study by Network ${ }^{65}$ reports that the p16 coding gene had an altered copy number in $46 \%$ of tested tumor samples. ${ }^{65}$ Many possible drug targets have been identified within the $\mathrm{pRb}$ pathway, but because multiple alterations have an additive effect in one pathway, it is vital to study and develop drugs that act independent of the p53 pathway. This approach, if successful, will allow better treatment of patients with more invasive bladder cancer and perhaps circumvent it altogether. It is also important to study the effects of drugs on urothelial cancer cell lines that have mutated p53 and altered expression of p21, p16, and pRb to better understand their roles in bladder tumorigenesis. Both T24 and UMUC3 human bladder cancer cell lines contain mutated p53 genes. ${ }^{71}$ T2 4 cells have an in-frame deletion of Y126, whereas UMUC3 cells have two mutations consisting of R72P and F113C. ${ }^{71,76}$ It is important to note that human T24 and UMUC3 cells have a mutation that is within the DNA binding domain of $\mathrm{p} 53$ protein, which has been shown to be a mutated in many cancers. ${ }^{77}$ The 126 and 113 residues of p53 are both close to the $\mathrm{K} 120$ residue, which has been shown to be a contact site interacting with the major groove of specific DNA sequences, ${ }^{78}$ suggesting that the mutant $\mathrm{p} 53$ protein of T24 and UMUC3 cell lines has a similar level of dysfunction. Furthermore, the UMUC3 cell line has an additional mutation that is within the proline-rich domain, which lies between the transactivation domain and the DNA binding domain. ${ }^{79}$ At the same time, both T24 and UMUC3 cell lines have been shown to be more resistant to radiation therapy when compared with cell lines containing a wild-type version of the p53 gene. ${ }^{76}$ Recently, Zhu et $\mathrm{al}^{72}$ have shown that silencing of mutant p53 in T24 cell line inhibited cell growth, induced apoptosis through caspase activation, and lowered the expression of cyclins A and B1. Lowering the expression of mutant p53 also sensitized bladder cancer cells to chemotherapeutic drugs. ${ }^{72}$ Another study showed that a mutant $\mathrm{p} 53$ protein can activate oncogenic genes, such as GEF-H1 at the transcription level in osteosarcoma cell line and increase cell proliferation. ${ }^{80}$ On the other hand, mutant p53 protein has been shown to be activated by small molecule drugs such as PRIMA-1 and is able to induce apoptosis in bladder cancer cells including T24 similar to the wild-type protein. ${ }^{81}$

While circumventing the p53 pathway has proven to be difficult, drugs such as doxorubicin have been shown to function in both a p53-dependent and -independent manner, which warrants further study on the efficacy of Dox and p53 pathway status. ${ }^{82}$ Because p53 is often accumulated inside neoplastic cells, it undergoes proteolysis and is processed to be expressed on the cell surface with human major histocompatibility complex HLA-A2. ${ }^{83}$ ALT-801, a drug currently in clinical studies, targets this unique surface representation of p53 peptide 264-272 with the HLA-A2 complex by an antibody linked to interleukin-2, which is capable of recruiting cytotoxic T-lymphocytes selectively to tumors ${ }^{84}$ (Table 2). Another method of targeting cell cycle abnormalities in bladder cancer is to use a nonspecific, antimitotic, or anti-DNA synthesis chemotherapeutic agent. Cisplatinbased therapies, including MVAC, have been extremely successful in the past. ${ }^{85}$ Several anticell cycle drugs, such as amrubicin - a derivative of the popular drug doxorubicin, are being researched to treat bladder cancer (Table 2).

\section{Receptor tyrosine kinase signaling pathways}

Receptor tyrosine kinase (RTK) pathways are commonly activated in earlier stage bladder cancer. RTKs are often deregulated in various types of cancers, and one major hallmark of malignancy is RTK independence from growth factors by amplification or an activating mutation. ${ }^{86}$ In bladder cancer, the altered RTKs include, but are not limited to, epidermal growth factor receptor (EGFR), ERBB2, ERBB3, and fibroblast growth factor receptor 3 (FGFR3). ${ }^{65}$ The downstream activators of RTKs are MAPKs and PI3K/AKT, which lead to the activation of many downstream products that induce cell proliferation.

In noninvasive bladder cancer, it is common to detect a mutation of the FGFR3 gene, or less commonly, a direct mutation of RAS itself. . $^{75,87,88}$ While mutation of the p53 tumor suppressor gene is very common in invasive bladder cancer, mutated FGFR3 and p53 are rarely found together. ${ }^{75,87}$ This may indicate two different models of initiation of bladder cancer, one leading to a far less aggressive cancer than the other. In another scenario, mechanistic target of rapamycin (mTOR), a downstream target of PI3K/AKT, has been linked to poor prognosis in bladder cancer patients with increased mortality ${ }^{89}$ One major obstacle is to determine which gene alterations in the tyrosine kinase pathway are associated with transition to a more invasive bladder cancer and select better drug targets for patients with recurrent or invasive bladder cancer. Another important consideration is the ability to select good candidate patients for therapies targeting various parts of the RTK signaling pathways. 
Table 2 Overview of clinical trials for bladder cancer

\begin{tabular}{|c|c|c|c|c|}
\hline Target pathway & Drug & Mechanism/target & Trial phase & Reference \\
\hline \multirow[t]{11}{*}{ Tyrosine kinase } & Bevacizumab & VEGF-A binding/inhibition & III & 95 \\
\hline & Ziv-aflibercept ${ }^{196}$ & VEGF binding/inhibiting agent & 1 & 196 \\
\hline & Cabozantinib & VEGFR-2 inhibitor & II & 197 \\
\hline & Pazopanib & Inhibitor of several tyrosine kinases & II & 198 \\
\hline & Tamoxifen & Antagonist of estrogen receptors & II & 199 \\
\hline & Buparlisib & PI3K inhibitor & II & 200 \\
\hline & Dovitinib & FGFR and VEGFR inhibitor & ॥ & 201 \\
\hline & MEKI62 & MEK inhibitor & II & 202 \\
\hline & MGAH22 & HER2-targeting antibody & I & 203 \\
\hline & Afatinib & EGFR and HER2 inhibitor & II & 94 \\
\hline & AZD5312 & Androgen receptor antisense inhibitor & I & 204 \\
\hline \multirow[t]{3}{*}{$\mathrm{PI} 3 \mathrm{~K} / \mathrm{AKT} / \mathrm{mTOR}$} & Everolimus & mTOR inhibitor (mTORCI and mTORC2) & I, II & 205 \\
\hline & Rapamycin & mTOR inhibitor & I, II & 206 \\
\hline & ABI-009 (albumin-bound rapamycin) & mTOR inhibitor & I, II & 207 \\
\hline \multirow[t]{12}{*}{ Immunotherapy } & ALT-80I & p53/HLA-A2-expressing tumor cells & I, II & 84 \\
\hline & HS-4IO & Immune activator along with BCG & I, II & 208 \\
\hline & ALT-803 & Immune activator through IL-15 & I, II & 209 \\
\hline & Ipilimumab & CTLA-4 antibody & ॥ & 117 \\
\hline & MEDI4736 & PDLI antibody antagonist & I & 111 \\
\hline & Tremelimumab & CTLA-4 antibody Down regulation of T-reg cells & I & 210 \\
\hline & AGSI5E & Slitrk6 targeting immunotherapy & 1 & 211 \\
\hline & MK-3745 (pembrolizumab) & PDLI & I, II & 110 \\
\hline & $\mathrm{Ad} / \mathrm{HER} 2 / \mathrm{Neu}$ vaccine & Vaccination/immune activation & 1 & 212 \\
\hline & SAR566658 & Anti-CA6-DM4 immunotherapy & I & 213 \\
\hline & Lenalidomide & Immunomodulation & I & 214 \\
\hline & MPDL3280A & Anti-PDLI immunotherapy & II & 112 \\
\hline \multirow[t]{8}{*}{ Cell cycle } & Eribulin mesylate & Microtubule formation/mitosis & I, II & 215 \\
\hline & Abraxane & Protein-bound paclitaxel - mitosis & I, II & 216 \\
\hline & Tesetaxel & Tubulin stabilization - antimitotic & ॥ & 217 \\
\hline & ASG-22CE & Inhibition of tubulin formation in cancer cells & 1 & 218 \\
\hline & & by targeting cells expressing adhesion molecule & & \\
\hline & & nectin-4 with monomethyl auristatin $E$ & & \\
\hline & Amrubicin & Anthracycline targeting topoisomerase II & II & 219 \\
\hline & Gemcitabine & Nucleoside analog targeting $S$ phase & III & 220 \\
\hline \multirow[t]{2}{*}{ Epigenetic changes } & $\begin{array}{l}\text { 5-Fluoro-2-deoxycytidine with } \\
\text { tetrahydrouridine }\end{array}$ & $\begin{array}{l}\text { Inhibition of DNA methylation/cytosine } \\
\text { deamination }\end{array}$ & II & 129 \\
\hline & Romidepsin & HDAC inhibitor & 1 & 128 \\
\hline \multirow[t]{4}{*}{ Other targets } & BBI608 & Cancer cell stemness & I, II & 221 \\
\hline & Ganetespib & Inhibition of HSP90 & 1 & 125 \\
\hline & OGX-427 & HSP27 inhibitor & ॥ & 126 \\
\hline & Veliparib & PARP inhibitor & I & 222 \\
\hline
\end{tabular}

Notes: Several studies used drugs in combination with other drugs as part of the traditional protocols for treatment of bladder cancer. This table does not represent all clinical trials sponsored by $\mathrm{NCl}$, but a selected subset of trials with relevance to this review article.

Abbreviations: VEGF, vascular endothelial growth factor; VEGFR, vascular endothelial growth factor receptor; mTOR, mechanistic target of rapamycin; mTORC, mTOR complex; PDLI, programmed death ligand I; EGFR, epidermal growth factor receptor; BCG, bacillus Calmette-Guérin; NCI, National Cancer Institute; HDAC, histone deacetylase; PARP, poly ADP ribose polymerase. FGFR, fibroblast growth factor receptor; MEK, mitogen-activated protein kinase kinase; PI3K, phosphatidylinositol-3-kinases; HER2, human epidermal growth factor receptor 2; HLA-A2, human leukocyte antigen A2; CTLA-4, cytotoxic T-lymphocyte-associated protein 4; HSP, heat shock protein.

As FGFR3 alterations are often associated with noninvasive and nonrecurrent bladder cancer, HER2 and EGFR alterations are associated with poor prognosis and more invasive bladder cancers. ${ }^{90-92}$ While these findings suggest that certain tyrosine kinase receptors may prove to be a valuable target for cancer therapy, each of them are overexpressed in a small subset of cancers. For example, a meta-analysis of 2,242 patients in nine separate studies showed that the incidence of ERBB2-positive (overexpressing) cancers ranged from $27.8 \%$ to $85.2 \%$, with the pooled average of ERBB2-positive cancers at $41.2 \% .{ }^{92}$

Another important RTK family protein is vascular endothelial growth factor receptor (VEGFR) and its ligands, which play an important role in angiogenesis, as well as cell survival and proliferation. Both VEGFR1 and VEGFR2 are overexpressed in bladder cancers, and bladder cancers express the vascular endothelial growth factor (VEGF) 
ligands for new blood vessel formation. ${ }^{93}$ Currently, there are a number of ongoing studies targeting RTKs in bladder cancer sponsored by the National Cancer Institute (NCI) (Table 2). RTK inhibitors function by inhibiting the receptor, as in the case of afatinib, which targets both EGFR and ERBB2 and has shown much promise by sensitizing murine bladder cancers to radiation. ${ }^{94}$ Bevacizumab, an antibody that binds to VEGF-A and inhibits its interaction with VEGFR, is currently under investigation as novel therapy for bladder cancer and renal cancers. ${ }^{95}$

Downstream of RTKs are cascades of signaling pathways, including the PI3K/AKT pathway. The PI3K/AKT pathway has been greatly implicated in the progression of bladder cancer. The ligand binds to RTK protein and is followed by self-phosphorylation of RTK and downstream activation of PI3K through the phosphorylation of the $\mathrm{p} 85$ subunit. The PI3K complex is responsible for the conversion of phosphatidylinositol 4,5-bisphosphate (PIP2) to phosphatidylinositol 3,4,5-trisphosphate (PIP3). PIP3 induces AKT activation by phosphorylation at the Tyr308 residue and, in turn, AKT phosphorylates AMPK as well as several other target proteins. Downstream of MAPK, through the inhibition of TSC $1 / 2$ by AKT, mTOR is activated and induces cell growth, survival, and further resistance to apoptosis. ${ }^{96}$ A negative regulator of the $\mathrm{PI} 3 \mathrm{~K} / \mathrm{AKT}$ pathway is the tumor suppressor gene PTEN, which is responsible for reverting PIP3 to PIP2. ${ }^{97}$ The inactivation of PTEN carries a poor prognosis in bladder cancer patients and this poor prognosis is further increased with the loss of p53, thus linking the p53 cell cycle pathway to the $\mathrm{PI} 3 \mathrm{~K} / \mathrm{AKT} / \mathrm{mTOR}$ pathway and suggesting the two pathways may work in combination to progress bladder cancer. ${ }^{97,98}$ One interesting feature about the PI3K/ AKT/mTOR pathway is that while it has been found to be altered in $72 \%$ of cancers, the alterations tend to be mutually exclusive, suggesting that altering only one gene in the pathway is enough to activate the downstream signaling cascade needed for enhanced tumorigenesis. ${ }^{65}$ For example, mutations in PI3K subunit PI3KCA, AKT3, and TSC1 were almost never found in the same tumor sample. ${ }^{65}$ Due to the variance and mutual exclusivity of these alterations, it will be extremely important to screen patients using genetic tests, as well as expression profiles, in order to better predict which patients are good candidates for the therapy targeting the specific proteins of the PI3K pathway. This makes the downstream target, mTOR, a valuable drug target for bladder cancer treatment. Drugs, currently under investigation, include rapamycin, albumin-bound rapamycin, and everolimus. One setback with using mTOR inhibitors such as rapamycin is that only the mTOR complex 1 (mTORC1) is sensitive to the drug, while the assembly of mTORC2 appears to be resistant. mTORC2 can phosphorylate AKT at the Ser473 residue and thus induce the AKT signaling cascade and still increase mTOR activation; through this feedback loop, cancer cells can develop resistance to mTOR-targeting therapies. ${ }^{99}$ New drugs such as everolimus inhibit the assembly of both mTORC1 and mTORC2, thus providing a more efficient tool to inhibit the PI3K/AKT/mTOR pathway. ${ }^{100}$

As bladder cancer progresses, more pathways are activated in order to facilitate survival, invasion, and metastasis. In bladder cancer, angiogenesis, measured by microvessel density, has proven to be an independent prognostic indicator when it comes to survival and, in some cases, staging. ${ }^{66,101}$ One of the main pathways activated in angiogenesis is the VEGF pathway that is directly regulated by hypoxia. ${ }^{66,101,102}$ When cells are depleted of oxygen, hypoxia-induced factor 1 and 2 (HIF-1 and HIF-2) are stabilized on the protein level. ${ }^{102}$ HIF-1 and HIF-2 are transcription factors that directly upregulate VEGF expression. ${ }^{102}$ Another way to increase VEGF expression is activation of the EGFR. ${ }^{103}$ Basic fibroblast growth factor (bFGF) is another angiogenic protein and has been shown to be an important prognostic marker in bladder cancer. ${ }^{104}$ The regulation of bFGF expression is increased upon the activation of the protein kinase $\mathrm{C}$ pathway, which is activated in most cancers by increasing cAMP concentration due to hypoxia and low energy levels. ${ }^{105}$ Inflammation in the cancer site and release of inflammatory signals such as interleukin-8 (IL-8) work as chemoattractants and also recruit blood vessel growth at the site inflammation. ${ }^{106,107}$ The p53 tumor suppressor, which is altered in many bladder cancers, has also been linked to angiogenesis. ${ }^{66}$

\section{Role of the immune system}

Treatment of bladder cancer has had a long history with immunotherapy in order to activate the immune system to target cancer cells. BCG, injected directly into the bladder as an adjuvant to chemotherapeutic agents, has been used for over three decades. ${ }^{108}$ Evasion of the immune system is a well-established hallmark of malignancy, and thus, increasing the efficacy of the immune system in bladder cancer has been an active area of research. ${ }^{86}$ There are two major approaches in targeting the immune system as an anticancer therapy. The first approach is to activate the immune system against the tumor by blocking or inhibiting negative regulators. The second approach is to increase the immune response using agonist cytokines. Programmed death ligand 1 (PDL1), along with its receptor programmed 
death 1 (PD1), has been implicated as one of the mechanisms cancer cells use to suppress immune response. PD1 is expressed on T-cells and is a negative regulator of T-cell response, whereas PDL1 is overexpressed by various types of cancers in order to suppress the immune response in the tumor environment. Tumor-infiltrating T-cells express high levels of PD1 and therefore are very sensitive to negative regulation by PDL $1 .{ }^{109}$ Several drugs target the PD1/PDL1 interaction, including MPDL3280A, pembrolizumab, and MEDI4736 (Table 2). For example, MK-3745, also known as pembrolizumab, is an antibody raised against the $\mathrm{PD} 1$ receptor and blocks the $\mathrm{PD} 1$ to PDL1 interaction. ${ }^{110}$ On the other hand, MEDI4736 and MPDL3280A are antibodies against the actual PDL1 ligand antibody, which block the interaction between PD1 and PDL1. ${ }^{11,112}$

Another negative regulator of the immune system is the CTLA-4 antigen, which is highly expressed on regulatory T-cells and serves to disrupt the cytotoxic T-cell response. ${ }^{113}$ Blocking antibodies of CTLA-4, including tremelimumab and ipilimumab, are currently under investigation to treat bladder cancer (Table 2). While studies using anti-CTLA-4 antibodies for bladder cancer are relatively new, both tremelimumab and ipilimumab have been effective in the treatment of lymphoma patients. Tremelimumab increases memory T-cell proliferation in lymphoma patients, thus potentiating a better immune response against cancer. ${ }^{114}$ Ipilimumab in combination with GP100 has increased the mean survival time of melanoma patients from an average of 6.4 months to an average of 10 months $(P$-value $<0.001) .{ }^{115,116}$ In renal cell convergence carcinoma, ipilimumab increased regression of the tumor in patients who previously did not respond to IL-2 immunotherapy; however, 14\% of patients experienced very high toxicity. ${ }^{117}$

Activation of the immune response against cancer has been intensively studied. In animal models, such as dogs, cancer-specific antigens were targeted with promising results. An Ad/HER2/Neu dendritic vaccine is currently being studied for treatment of bladder cancer (Table 2). It is vital to test for positive expression of ERBB2 prior to treatment because it has been shown that ERBB2 is altered in $12 \%$ of bladder cancer patients either by mutation or copy number amplification, making it a target for a very small subset of patients. ${ }^{65}$ Another approach in activating the immune system against cancer is to use drugs such as ALT801, an IL-2-based immunotherapy, and ALT803, an IL-15-based immunotherapy (Table 2). These cytokines are agonists to immune response. IL-2 and IL-15 work by recruiting more cytotoxic T-lymphocytes to the tumor and helping convert naïve T-cells to effector cytotoxic T-lymphocytes. ${ }^{118,119}$ As mentioned earlier, ALT801 targets the p53-HLA-A2 complex, thus both targeting a defective p53 pathway while activating the immune response to the tumor. ${ }^{84}$

\section{Role of the other molecular targets and signaling pathways}

Heat shock proteins (HSPs) have been shown to affect cancer by stabilizing oncogenic proteins as well as eliciting selfrecognition (negative regulatory immune response) and have been observed to be overexpressed in various cancers. ${ }^{120,121}$ For example, HSP90 has been shown to stabilize RAFmutated protein, which is downstream of RAS, activate the RAS-ERK pathway in cancer cells, and can also activate the PI3K pathway mentioned earlier. ${ }^{122}$ HSP27 has been shown to modulate p53 signaling by inhibiting the induction of p21, causing resistance to doxorubicin therapy in human breast cancer cells. ${ }^{123}$ Ganetespib and OGX-427 are being investigated for bladder cancer treatment. Ganetespib, an HSP90 inhibitor, has shown much promise in lung cancer and has increased the efficacy of other therapies while being well tolerated with low toxicity in cancer patients. ${ }^{124,125}$ OGX-427, an antisense oligonucleotide-based therapy against HSP27, has been shown to be effective against the bladder cancer cell line UMUC3 by increasing activation of the caspase cascade, increasing efficacy to paclitaxel, and slowing tumor growth in a xenograft model. ${ }^{126}$

Epigenetics have been known to play an important role in cancer for the past two decades. Hypermethylation of the promoter regions coding tumor suppressor genes, such as p14, p16, and APC, is often detected in bladder cancers. ${ }^{127}$ Genetic profiling recently revealed that $89 \%$ of bladder cancers contain altered histone modification pathways and $64 \%$ of cancers contain alterations in the SWI/SNF complex, which is responsible for chromatin remodeling in order to turn on or turn off transcription. ${ }^{65}$ Romidepsin, a histone deacetylase inhibitor, and 5-fluoro-2-deoxycytidine in combination with tetrahydrouridine are being studied for bladder cancer to inhibit DNA methylation and deamination. ${ }^{128,129}$ Recently, the histone deacetylase inhibitor AR-42 has shown promise in combination with cisplatin in treating bladder cancer in the mouse model. It was also shown that AR-42, when combined with cisplatin, can be an effective treatment on cancer stem cell populations in vitro. ${ }^{130}$ Recent study by Chen et al ${ }^{131}$ has shown that targeted gene therapy using RAN promoter, which regulates the expression of constitutively active form 
of caspase-3, reduced tumor burden and decreased inflammation in orthotopic model of murine bladder cancer after only three treatments in vivo.

Epithelial to mesenchymal transition (EMT) has been shown to play an important role in invasion and metastasis. In order for cells to migrate from the primary site to a secondary site, they must exhibit plasticity to adapt to new environments. ${ }^{132}$ Altered integrin expression can facilitate EMT by increasing the expression of mesenchymal genes, while decreasing the expression of epithelial genes. ${ }^{133}$ Integrin proteins not only change how cells interact with the extracellular matrix (ECM) but can also trigger signal transduction pathways, such as the PI3K/AKT signaling pathway. ${ }^{134}$ It has been shown that the $\alpha \mathrm{V}$ group of integrins is expressed in metastatic bladder cancer in a stage/gradedependent manner. ${ }^{135}$ Several approaches to target integrins are under development for treatments of bladder cancer. ${ }^{136-139}$ Because integrins interact with specific ECM components with different affinity, an Arg-Gly-Asp peptide was synthesized to bind $\alpha \mathrm{VB} 3$ and $\alpha \mathrm{VB} 5$ integrins and was inserted into the fiber protein to facilitate adenovirus infection. The Arg-Gly-Asp motif increased transfection efficiency of bladder cancer cells with the adenovirus and will perhaps lead to further advances in oncolytic viral research for bladder cancer. ${ }^{137}$ GLPG0187, a small molecule integrin receptor antagonist, has been shown to decrease migration and invasion in bladder cancer cells and has also been shown to decrease tumor burden in the mouse xenograft model using UMUC3 bladder cancer cells. ${ }^{138}$ Change in integrin structure may also play a role in EMT. Integrin $\alpha 3 \beta 1$ has been shown to be abnormally glycosylated in bladder cancer cells, thus increasing its interaction with CD9. ${ }^{139}$ A recently developed antibody against integrin $\alpha 3 \beta 1$, BCMab1, has been shown to play a prognostic role in cancer patients: patients with low expression of BCMab1 exhibited longer survival than the patients with higher expression. At the same time, BCMab1 has shown antitumor activity through natural killer T-cell and macrophage recruitment in vitro and reduced tumor burden in a mouse xenograft model in vivo. ${ }^{140}$

Inflammation plays an important role in development and progression of bladder cancer. The non-steroidal antiinflammatory drugs, such as piroxicam increase the efficacy of chemotherapy. ${ }^{107} \mathrm{COX}-2$ has been shown to be overexpressed in many cancers, including bladder cancer. ${ }^{141}$ In addition, the inflammatory protein COX-2 is being actively studied as molecular target for detection and treatments of cancers. ${ }^{39,107,142}$ Perinuclear localization of COX-2 has been associated with bladder cancer cells expressing stem cell-like markers, including OCT 3/4 and CD44v6. COX-2driven inflammation helps to drive proliferation of cancer stem cells (CSCs). ${ }^{143}$

\section{Cancer stem cells}

Other studies of bladder cancer have suggested a new approach for treatment by targeting tumor-initiating cells or CSCs. CSCs are cancer cells with unique properties such as self-renewal, and drug-resistance. ${ }^{144}$ A subpopulation of CSCs have been isolated from various cancers, including bladder cancer tumors. ${ }^{145}$ It has been reported that STAT3 activation is required for the acquisition of CSC-like properties in breast cancer. ${ }^{146}$ It has also been reported that bladder cancer basal cells, which exhibit CSC-like properties, closely resemble breast cancer basal cells, which also exhibit CSC-like properties. ${ }^{147}$ A novel small molecule inhibitor of STAT3, BBI608, is currently being studied in human bladder cancer patients in an NCI-sponsored study. Chemotherapy can actually cause a selective increase in $\mathrm{CSC}$ in some tumors. In a pancreatic cancer xenograft model, gemcitabine, while inducing an anticancer response initially, attributed to an increase in CSCs and induced a larger tumor load in the animal than the control 15 days after the drug was discontinued. On the other hand, BBI608 showed a lower tumor load when compared with both control and gemcitabine 15 days after drug treatment was discontinued. ${ }^{148}$ Gemcitabine and cisplatin induce COX-2 expression in bladder cancer cells and increase downstream expression of prostaglandin E2 (PGE2). Released PGE2 from apoptotic cells can induce CSC-like characteristics in neighboring cells. Inhibition of COX-2 by celecoxib inhibited repopulation of bladder cells after several gemcitabine and cisplatin treatments and reduced CSC-like characteristics in neighboring cells. ${ }^{149,150}$

\section{Animal models of bladder cancer Rodent models}

Numerous experimental rodent models of bladder cancer have been established and characterized to study epidemiology and carcinogenesis of bladder cancer. ${ }^{151}$ Bladder cancer models in rodents can be chemically induced, genetically engineered, or transplantable. ${ }^{151}$

The most commonly used carcinogens to induce bladder cancer in mice are $N$-butyl- $N$-(4-hydroxybutyl) nitrosamine (BBN), $N$-[4-(5-nitro-2-furyl)-2-thiazolyl] formamide, and $\mathrm{N}$-methyl-N-nitosurea. ${ }^{75} \mathrm{BBN}$ via drinking water, diet, or gastric intubation induces bladder tumors in mice. ${ }^{152,153}$ Mice exposed to BNN develop nodular invasive 
carcinoma preceded by carcinoma in situ, and develop polypoid exophytic cancers with late muscle invasion. ${ }^{153}$ Rodent bladder tumors induced by BBN mirror their human counterparts histologically and genetically. ${ }^{154}$ A study comparing mRNA and protein levels of the rodent bladder cancer model with human bladder cancer, shows concordant similarities in several genes/proteins, demonstrating that the bladder cancer model induced by BBN is a powerfully reliable study tool. ${ }^{155}$ These rodent models provide useful information concerning the risk of chemical exposure and bladder cancer; however, they have limitations due to lowgrade tumors and low rates of metastasis. ${ }^{156}$ Also, tumor induction and progression take time and are dependent on carcinogen and dosage.

Transgenic mice or genetically engineered mice (GEM) are generated by cloning oncogenes or by deletion of tumor-suppressing genes, individually or in combination. ${ }^{151}$ GEM models have provided increasing insight on the role of numerous genes, such as HRAS, ${ }^{157} \mathrm{p} 53,{ }^{98} \mathrm{pRB},{ }^{158}$ and PTEN, ${ }^{98}$ and receptors such as FGFR ${ }^{88}$ and EGFR ${ }^{159}$ in the development of bladder cancer. With target genes switched on or off, GEM are ideal for studying single or multiple gene functions, however, these models may not fully reflect the genetic alterations in human tumorigenesis as it involves the deregulation of multiple signaling pathways. ${ }^{151}$ Cancer cells in these models are less heterogeneous than human bladder cancer, ${ }^{160}$ and GEM are usually not used to test the efficacy of novel therapeutic or preventive agents. ${ }^{151}$

Xenogeneic models involve the implantation of human bladder cancer cells into an immune-deficient mouse. Various commercially available TCC cell lines, such as KU7, KU-19-19, T24, UMUC1, UMUC3, and UMUC13, have been used to develop tumors in immunodeficient mice. ${ }^{160}$ A major disadvantage of this technique is that the immune response, which is an important factor regulating tumor growth, cannot be assessed because of the immunodeficient nature of the host. ${ }^{75}$ Syngeneic models, in contrast to xenogeneic models, are established by inoculating rodent bladder cancer to syngeneic, immunocompetent animals. ${ }^{151}$ The commonly used rodent bladder cancer cell lines for syngeneic modeling are AY-27, MBT-2, and MB49. ${ }^{151}$ Tumors induced by this model are of rodent and not human origin, and therefore, various characteristics, including tumor growth, latency, growth rate, invasion, and metastasis, may be different from their human counterparts. ${ }^{161,162}$

Based on whether the inoculation site is in the target organ, xenogeneic and syngeneic models could be further divided into orthotopic and heterotopic models. In orthotopic models, inoculation is done at the primary site from which the tumor lines were derived. ${ }^{163}$ These tumors mimic human bladder cancer behavior more closely, since the microenvironment is closer to natural conditions. ${ }^{151}$ The disadvantage of the orthotopic human tumor xenograft model is that the surgeries are often complex, leading to high morbidity of mice. ${ }^{160}$

In heterotopic models, the graft is not transplanted at the original site, but is usually subcutaneously placed in the flank or hind leg of the animal. This process is technically simple, and the tumor can be easily and noninvasively detected. Subcutaneous bladder tumor models have been widely used in assessing the efficacy of novel therapeutic agents. ${ }^{163}$ However, as the inoculation site is different from the original tumor site, the alteration of the tumor microenvironment may significantly affect the biological behavior of tumor growth and metastasis, genetic expression, or the efficacy of antiproliferative agents. ${ }^{164}$

The rodent cancer models have several advantages, including small body size, short gestation, inexpensive maintenance, and easy manipulation of gene expression. ${ }^{165}$ However, the average rate of successful translation from mouse model to clinical cancer trials is $<8 \%$. ${ }^{166}$ Also, a mouse model can tolerate higher drug concentrations than human patients. Considering the vast species differences between mice and humans, it is important to use other animal models, such as companion dogs with naturally occurring bladder cancer. ${ }^{165}$

\section{Canine models}

Urinary bladder cancer is an uncommon type of cancer in dogs ( $<2 \%$ of all canine malignancies) ${ }^{167}$ however, $97 \%$ of diagnosed bladder tumors in dogs are malignant. ${ }^{39}$ Bladder canine TCC is the most common neoplasm affecting the urinary tract of dogs. ${ }^{168}$ Risk factors that have been identified include exposure to insecticides ${ }^{169}$ and cyclophosphamides. ${ }^{170}$ The female-to-male ratio of dogs with TCC has been reported to range from 1.71:1 to $1.95: 1$, with increased risk after spaying and neutering. ${ }^{171-173}$ Scottish terriers have a strong breed-associated risk factor for the bladder cancer. ${ }^{173}$ In addition to spontaneous bladder cancer, tumors can be experimentally induced in dogs in a laboratory setting with chemical carcinogens, such as BBN. ${ }^{174}$

Naturally occurring bladder cancer in dogs very closely mimics human invasive bladder cancer, specifically highgrade invasive TCC, in cellular and molecular features; biological behavior, including sites and frequency of metastasis; and response to therapy. Incidence of TCC in both humans and dogs is $2 \%$ of all cancers. ${ }^{167}$ TCC occurs in older dogs at an average age of 11 years, which is equivalent 
to 60 years in humans. ${ }^{175}$ Both human and canine TCCs have similar risk factors, including exposure to various chemicals, such as insecticides and aromatic hydrocarbons. ${ }^{169,176}$

Histopathology of canine TCC is similar to human bladder cancer, with invasive TCC of intermediate to high grade existing in both species. ${ }^{168,176}$ Distant metastasis has been reported in 15\%-20\% of dogs diagnosed with TCC, ${ }^{172}$ which is similar to humans, in which metastasis occurs in $5 \%-20 \%$ of patients. ${ }^{176}$ The sites involved in metastasis are also similar between dogs and humans and include lymph node, lung, bone, liver, and kidney. ${ }^{177}$ Various similarities in cellular and molecular levels in canine and human TCC have been studied so far, including similar lipidomic profiling in both species. ${ }^{178}$ Both human and canine TCCs have shown overexpression of COX-2 in tumor cells. ${ }^{141,179}$ Platinum-based chemotherapies are considered the most active agent in the treatment of TCC in both species. ${ }^{172,176}$ The main difference between TCC in dogs and humans is sex predilection: in humans, TCC is almost three times more common in males than in females, ${ }^{173,180}$ whereas in dogs, it is less common in males, with a 2:1 female:male ratio. ${ }^{171,173}$ The location of TCC within the bladder also differed in dogs and humans: in humans, majority of TCC is localized in the lateral and posterior walls of the bladder, ${ }^{181}$ whereas in dogs most TCC is trigonal in location with extension to the urethra. ${ }^{172}$

TCC typically occurs in older dogs ranging from 9 years to 11 years of age. ${ }^{177}$ Clinical staging of canine bladder cancer is performed with complete physical examination, radiography of the thorax and abdomen, and imaging of the bladder using contrast cystography, ultrasonography, or CT. ${ }^{168}$ The TNM classification scheme for canine urinary bladder cancer has been defined by the World Health Organization and is much like the staging system used for human cancers. ${ }^{182}$ Each TNM stage is further divided into substages, as shown in Table $1 .{ }^{182}$

Treatment options of TCC in dogs include surgery, radiation therapy, chemotherapy and other drugs, and combinations of these treatments. The surgical complete cystectomy, although it may be routine in human bladder cancer patients, has not been attempted to any extent in the dog. Canine TCC is difficult to be removed surgically because of the trigonal location of the tumor, frequency of urethral involvement, and metastases in $20 \%$ or more of dogs at the time of diagnosis. ${ }^{168,177}$ Radiation therapy is not routinely used to treat canine TCC due to various side effects, including pollakiuria, urinary incontinence, cystitis, stranguria, and hydronephrosis. ${ }^{183}$ Chemotherapy drugs used in canine TCC include cisplatin, carboplatin, mitoxantrone, adriamycin, and actinomycin D as single agents. ${ }^{173}$ Various combination therapies have also been used. Other treatment options include nonsteroidal anti-inflammatory drugs (NSAIDs) such as piroxicam as a single agent ${ }^{184}$ or in combination with chemotherapy drugs. ${ }^{185,186}$

Dogs diagnosed with spontaneous tumors offer a unique model to study bladder cancer development and detection, as well as evaluation of new therapies. ${ }^{165}$ Dogs offer an exceptional opportunity to study potential genetic and environmental risk factors for TCC and develop early detection and intervention strategies. Development of new treatment options in the dog model can provide translational value to ultimately help develop better drugs for people with TCC. Single agent NSAIDs such as piroxicam, deracoxib, and firocoxib have shown positive results in treating dog TCC; ${ }^{172}$ further translation of this treatment option to humans is an obvious next step. A pilot study has shown positive results in the treatment of human TCC using the NSAID celecoxib. ${ }^{187}$ Folate-targeted therapy has been used for treatment of several forms of human cancers, including ovarian and lung cancer. ${ }^{188}$ Recently, a dog study was conducted to determine the potential role of folate-targeted therapy in the treatment of canine TCC. ${ }^{189}$ Further epigenetic-based therapy using 5-azacitidine has been tested to treat canine TCC. ${ }^{190}$ Metronomic chemotherapy, based on frequent and repetitive treatment with low-dose chemotherapeutic drugs to delay the progression of cancer, ${ }^{191}$ has been recently used to treat canine TCC. ${ }^{192}$ The positive outcome of this trial can help inform future investigations into new treatment options for human TCCs. Fluorocoxib A, a COX-2-specific inhibitor conjugated with rhodamine, ${ }^{38}$ has shown to specifically detect COX-2-expressing TCC cells in vitro and in dogs during cystoscopy in vivo. ${ }^{39,193}$

Spontaneously occurring TCC in dogs shares molecular and clinical characteristics with human cancers. ${ }^{165}$ Use of canine models can lead to better understanding and new therapeutic development for treatment of human TCC. Primary K9TCC cell lines are currently available and can also help in the study of various drugs in vitro before clinical trials. ${ }^{194,195}$ Therefore, utilizing the dog model in TCC research can benefit animal and human diseases.

The advantages and disadvantages of animal models of bladder cancer used for various studies to validate novel therapeutic, imaging, or preventive agents to advance knowledge of bladder cancer are summarized in Table 3.

\section{Conclusion}

With increasing knowledge of specific pathways activated or altered in bladder cancer, an increasing number of new, promising therapies are on the horizon. In the future, it will 
Table 3 Advantages and disadvantages of animal models of bladder cancer

\begin{tabular}{|c|c|c|c|c|}
\hline Type & Mechanism & Advantages & Disadvantages & Remarks \\
\hline $\begin{array}{l}\text { Chemically } \\
\text { induced mice } \\
\text { model }\end{array}$ & $\begin{array}{l}\text { Induced by carcinogens: } \\
\text { BBN, FANFT, and MNU }\end{array}$ & $\begin{array}{l}\text { Provides information about the risk of } \\
\text { chemical exposure }\end{array}$ & $\begin{array}{l}\text { Low-grade tumors and } \\
\text { low rates of metastasis } \\
\text { Tumor induction } \\
\text { depends on carcinogen } \\
\text { and dosage }\end{array}$ & $\begin{array}{l}\text { Studies to validate the } \\
\text { effects of the environmental } \\
\text { agents and for evaluation of } \\
\text { molecular mechanisms during } \\
\text { carcinogenesis }\end{array}$ \\
\hline $\begin{array}{l}\text { Genetically } \\
\text { engineered } \\
\text { mice model }\end{array}$ & $\begin{array}{l}\text { Induced by cloning } \\
\text { oncogenes and/or } \\
\text { deleting tumor- } \\
\text { suppressing genes }\end{array}$ & $\begin{array}{l}\text { Provides information on the role of } \\
\text { specific genes such as oncogenes and } \\
\text { tumor suppressors }\end{array}$ & $\begin{array}{l}\text { Homogeneous } \\
\text { population of cancer cells }\end{array}$ & $\begin{array}{l}\text { Studies to evaluate the effects } \\
\text { of specific genes for bladder } \\
\text { tumorigenesis } \\
\text { Studies to test novel } \\
\text { therapeutic, imaging, or } \\
\text { preventive agents }\end{array}$ \\
\hline $\begin{array}{l}\text { Xenogeneic } \\
\text { mice model }\end{array}$ & $\begin{array}{l}\text { Induced by implanting } \\
\text { bladder cancer cells, } \\
\text { eg, human into immune- } \\
\text { deficient mouse }\end{array}$ & $\begin{array}{l}\text { Tumors are of nonrodent origin } \\
\text { eg, human }\end{array}$ & $\begin{array}{l}\text { Immune response } \\
\text { cannot be assessed } \\
\text { Homogeneous } \\
\text { population of cancer cells }\end{array}$ & $\begin{array}{l}\text { Studies to test novel } \\
\text { therapeutic, imaging, or } \\
\text { preventive agents }\end{array}$ \\
\hline $\begin{array}{l}\text { Syngeneic } \\
\text { mice model }\end{array}$ & $\begin{array}{l}\text { Induced by implanting } \\
\text { rodent bladder cancer } \\
\text { cells into immune- } \\
\text { deficient mouse }\end{array}$ & $\begin{array}{l}\text { Tumor microenvironment is same as } \\
\text { the tumor is of rodent origin } \\
\text { Tumors induced are of rodent origin }\end{array}$ & $\begin{array}{l}\text { Homogeneous } \\
\text { population of cancer cells }\end{array}$ & $\begin{array}{l}\text { To test novel therapeutic, } \\
\text { imaging, or preventive agents }\end{array}$ \\
\hline $\begin{array}{l}\text { Orthotopic } \\
\text { mice model }\end{array}$ & $\begin{array}{l}\text { Induced by implanting } \\
\text { the bladder cancer cells } \\
\text { into bladder }\end{array}$ & $\begin{array}{l}\text { Mimic human bladder cancer behavior } \\
\text { as microenvironment is closer to } \\
\text { natural conditions }\end{array}$ & $\begin{array}{l}\text { High morbidity of mice } \\
\text { connected with the } \\
\text { surgery of the bladder } \\
\text { cancer cells implantation } \\
\text { Homogeneous } \\
\text { population of cancer cells }\end{array}$ & $\begin{array}{l}\text { To test novel therapeutic, } \\
\text { imaging, or preventive agents }\end{array}$ \\
\hline $\begin{array}{l}\text { Heterotopic } \\
\text { mice model }\end{array}$ & $\begin{array}{l}\text { Induced by implanting } \\
\text { the bladder cancer cells } \\
\text { at the different sites/ } \\
\text { organs such as bladder, } \\
\text { usually subcutaneous }\end{array}$ & $\begin{array}{l}\text { Technically simple model } \\
\text { Tumor can be noninvasively detected }\end{array}$ & $\begin{array}{l}\text { Inoculation site/organ } \\
\text { is different, thereby the } \\
\text { tumor microenvironment } \\
\text { is altered } \\
\text { Homogeneous } \\
\text { population of cancer cells }\end{array}$ & $\begin{array}{l}\text { To test novel therapeutic, } \\
\text { imaging, or preventive agents }\end{array}$ \\
\hline $\begin{array}{l}\text { Companion } \\
\text { animals with } \\
\text { bladder cancer }\end{array}$ & $\begin{array}{l}\text { Spontaneously } \\
\text { occurring bladder } \\
\text { cancer in dogs and cats }\end{array}$ & $\begin{array}{l}\text { Naturally occurring heterogeneous } \\
\text { population of cancer cells } \\
\text { More similar biological and histological } \\
\text { appearance to human cancer response } \\
\text { to cytotoxic agents } \\
\text { Shorter overall life span and more } \\
\text { rapid disease progression }\end{array}$ & $\begin{array}{l}\text { More costly than rodent } \\
\text { model }\end{array}$ & $\begin{array}{l}\text { To test novel therapeutic, } \\
\text { imaging, or preventive agents } \\
\text { for papillary and muscle- } \\
\text { invasive bladder cancer } \\
\text { Epidemiological studies }\end{array}$ \\
\hline
\end{tabular}

Abbreviations: BBN, N-butyl-N-(4-hydroxybutyl) nitrosamine; FANFT, N-[4-(5-nitro-2-furyl)-2-thiazolyl] formamide; MNU, N-methyl-N-nitrosourea.

be extremely important to test patients for personalized therapies because these therapies target only a small subset of patients. This pathway knowledge will also increase the knowledge base of potential drug targets for new and exciting drug development.

\section{Acknowledgments}

We thank the National Institute of Health (R15-CA18285001A1; PI: Cekanova), the University of Tennessee the Center of Excellence in Livestock Diseases and Human Health grants (R181721333; PI: Cekanova), and Department of Small Animal Clinical Sciences (E180120; PI: Cekanova) for supporting this research.

\section{Author contributions}

DS wrote and approved final manuscript, designed tables, and agreed to be accountable for all aspects of the work. $\mathrm{KR}$ wrote and approved final manuscript and agreed to be accountable for all aspects of the work. MC designed, wrote, and approved final manuscript; designed tables; and agreed to be accountable for all aspects of the work. All authors contributed toward data analysis, drafting and critically revising the paper and agree to be accountable for all aspects of the work.

\section{Disclosure}

The authors report no conflicts of interest in this work. 


\section{References}

1. National Cancer Institute [webpage on the Internet]. SEER Stat Fact Sheets: Bladder Cancer. 2016. Available from: http://seer.cancer.gov/ statfacts/html/urinb.html. Accessed February 4, 2016.

2. American Cancer Society. Cancer Facts \& Figures. Atlanta, GA: American Cancer Society; 2016.

3. Siegel R, Ma J, Zou Z, Jemal A. Cancer statistics, 2014. CA Cancer J Clin. 2014;64(1):9-29.

4. Weill Cornell Medical College [webpage on the Internet]. Types of Bladder Cancers. 2015. Available from: https://www.cornellurology. com/clinical-conditions/bladder-cancer/types-of-bladder-cancers/. Accessed August 10, 2015.

5. Cancer Research UK [webpage on the Internet]. Types of Bladder Cancer. 2015. Available from: http://www.cancerresearchuk.org/aboutcancer/type/bladder-cancer/about/types-of-bladder-cancer. Accessed August 12, 2015.

6. Kaufman DS, Shipley WU, Feldman AS. Bladder cancer. Lancet. 2009;374(9685):239-249.

7. Kantor AF, Hartge P, Hoover RN, Fraumeni JF. Epidemiological characteristics of squamous cell carcinoma and adenocarcinoma of the bladder. Cancer Res. 1988;48(13):3853-3855.

8. Lott S, Lopez-Beltran A, Montironi R, MacLennan GT, Cheng L. Soft tissue tumors of the urinary bladder: part II: malignant neoplasms. Hum Pathol. 2007;38(7):963-977.

9. Kirkali Z, Chan T, Manoharan M, et al. Bladder cancer: epidemiology, staging and grading, and diagnosis. Urology. 2005;66(6 suppl 1): 4-34.

10. Reid LM, Leav I, Kwan PW, Russell P, Merk FB. Characterization of a human, sex steroid-responsive transitional cell carcinoma maintained as a tumor line (R198) in athymic nude mice. Cancer Res. 1984;44(10): 4560-4573.

11. Mallin K, David KA, Carroll PR, Milowsky MI, Nanus DM. Transitional cell carcinoma of the bladder: racial and gender disparities in survival (1993 to 2002), stage and grade (1993 to 2007). J Urol. 2011; 185(5):1631-1636.

12. Yee DS, Ishill NM, Lowrance WT, Herr HW, Elkin EB. Ethnic differences in bladder cancer survival. Urology. 2011;78(3):544-549.

13. Calle EE, Rodriguez C, Walker-Thurmond K, Thun MJ. Overweight, obesity, and mortality from cancer in a prospectively studied cohort of US adults. New Engl J Med. 2003;348(17):1625-1638.

14. Qin Q, Xu X, Wang X, Zheng XY. Obesity and risk of bladder cancer: a meta-analysis of cohort studies. Asian Pac J Cancer Prev. 2013; 14(5):3117-3121.

15. Wyszynski A, Tanyos SA, Rees JR, et al. Body mass and smoking are modifiable risk factors for recurrent bladder cancer. Cancer. 2014;120(3):408-414.

16. Villanueva CM, Fernandez F, Malats N, Grimalt JO, Kogevinas M. Meta-analysis of studies on individual consumption of chlorinated drinking water and bladder cancer. J Epidemiol Community Health. 2003;57(3):166-173.

17. Ferrís J, Berbel O, Alonso-López J, Garcia J, Ortega JA. Environmental non-occupational risk factors associated with bladder cancer. Actas Urol Esp. 2013;37(9):579-586.

18. Mink PJ, Alexander DD, Barraj LM, Kelsh MA, Tsuji JS. Low-level arsenic exposure in drinking water and bladder cancer: a review and meta-analysis. Regul Toxicol Pharmacol. 2008;52(3):299-310.

19. Chu HA, Crawford-Brown DJ. Inorganic arsenic in drinking water and bladder cancer: a meta-analysis for dose-response assessment. Int J Environ Res Public Health. 2006;3(4):316-322.

20. Burger M, Catto JW, Dalbagni G, et al. Epidemiology and risk factors of urothelial bladder cancer. Eur Urol. 2013;63(2):234-241.

21. Freedman ND, Silverman DT, Hollenbeck AR, Schatzkin A, Abnet CC Association between smoking and risk of bladder cancer among men and women. JAMA. 2011;306(7):737-745.

22. Chen $\mathrm{CH}$, Shun $\mathrm{CT}$, Huang KH, et al. Stopping smoking might reduce tumour recurrence in nonmuscle-invasive bladder cancer. BJU Int. 2007; 100(2):281-286.
23. Sathiakumar N, MacLennan PA, Mandel J, Delzell E. A review of epidemiologic studies of triazine herbicides and cancer. Crit Rev Toxicol. 2011;41(S1):1-34.

24. Gaertner RR, Theriault GP. Risk of bladder cancer in foundry workers: a meta-analysis. Occup Environ Med. 2002;59(10):655-663.

25. Koutros S, Karagas M, Friesen M, et al. 0118 lifetime occupational exposure to diesel exhaust and bladder cancer among men in New England. Occup Environ Med. 2014;71(suppl 1):A75.

26. Travis LB, Curtis RE, Glimelius B, et al. Bladder and kidney cancer following cyclophosphamide therapy for non-Hodgkin's lymphoma. J Natl Cancer Inst. 1995;87(7):524-530.

27. Fletcher O, Easton D, Anderson K, Gilham C, Jay M, Peto J. Lifetime risks of common cancers among retinoblastoma survivors. $J$ Natl Cancer Inst. 2004;96(5):357-363.

28. Pavanello S, Mastrangelo G, Placidi D, et al. CYP1A2 polymorphisms, occupational and environmental exposures and risk of bladder cancer. Eur J Epidemiol. 2010;25(7):491-500.

29. Nauwelaërs G, Bellamri M, Fessard V, Turesky RJ, Langouët S. DNA adducts of the tobacco carcinogens 2-amino-9 H-pyrido [2, 3-b] indole and 4-aminobiphenyl are formed at environmental exposure levels and persist in human hepatocytes. Chem Res Toxicol. 2013;26(9): 1367-1377.

30. Bladder Cancer Diagnosis [webpage on the Internet]. Bladder Cancer. 2015. Available from: http://www.cancer.org/cancer/bladdercancer/ detailedguide/bladder-cancer-diagnosis. Accessed August 10, 2015.

31. Tilki D, Burger M, Dalbagni G, et al. Urine markers for detection and surveillance of non-muscle-invasive bladder cancer. Eur Urol. 2011; 60(3):484-492.

32. Fradet Y, Grossman HB, Gomella L, et al. A comparison of hexaminolevulinate fluorescence cystoscopy and white light cystoscopy for the detection of carcinoma in situ in patients with bladder cancer: a phase III, multicenter study. J Urol. 2007;178(1):68-73.

33. Karaoglu I, van der Heijden AG, Witjes JA. The role of urine markers, white light cystoscopy and fluorescence cystoscopy in recurrence, progression and follow-up of non-muscle invasive bladder cancer. World $J$ Urol. 2014;32(3):651-659.

34. Grossman HB, Gomella L, Fradet Y, et al. A phase III, multicenter comparison of hexaminolevulinate fluorescence cystoscopy and white light cystoscopy for the detection of superficial papillary lesions in patients with bladder cancer. J Urol. 2007;178(1):62-67.

35. Karl A, Tritschler S, Stanislaus P, et al. Positive urine cytology but negative white-light cystoscopy: an indication for fluorescence cystoscopy? BJU Int. 2009;103(4):484-487.

36. Kim T, Griffin JG, Holzbeierlein JM, Sexton WJ. Imaging in localized and advanced bladder cancer. Management of Bladder Cancer. New York City: Springer; 2015:59-71.

37. de Boer E, Harlaar NJ, Taruttis A, et al. Optical innovations in surgery. Br J Surg. 2015;102(2):e56-e 72.

38. Uddin MJ, Marnett LJ. Synthesis of 5- and 6-carboxy-X-rhodamines. Org Lett. 2008;10(21):4799-4801.

39. Cekanova M, Uddin MJ, Bartges JW, et al. Molecular imaging of cyclooxygenase-2 in canine transitional cell carcinomas in vitro and in vivo. Cancer Prev Res (Phila). 2013;6(5):466-476.

40. Uddin MJ, Crews BC, Blobaum AL, et al. Selective visualization of cyclooxygenase- 2 in inflammation and cancer by targeted fluorescent imaging agents. Cancer Res. 2010;70(9):3618-3627.

41. American Cancer Society [webpage on the Internet]. How Is Bladder Cancer Found? 2015. Available from: http://www.cancer.org/cancer/ bladdercancer/overviewguide/bladder-cancer-overview-diagnosed. Accessed August 28, 2015.

42. Blick CG, Nazir SA, Mallett S, et al. Evaluation of diagnostic strategies for bladder cancer using computed tomography (CT) urography, flexible cystoscopy and voided urine cytology: results for 778 patients from a hospital haematuria clinic. BJU Int. 2012;110(1):84-94.

43. Hafeez S, Huddart R. Advances in bladder cancer imaging. $B M C$ Med. 2013;11(1):104.

44. Tekes A, Kamel I, Imam K, et al. Dynamic MRI of bladder cancer: evaluation of staging accuracy. Am J Roentgenol. 2005;184(1):121-127. 
45. Nicolau C, Bunesch L, Peri L, et al. Accuracy of contrast-enhanced ultrasound in the detection of bladder cancer. Br J Radiol. 2011; 84(1008):1091-1099.

46. Sun M, Trinh QD. Diagnosis and staging of bladder cancer. Hematol Oncol Clin North Am. 2015;29(2):205-218,vii.

47. American Cancer Society [webpage on the Internet]. Bladder Cancer Staging. 2014. Available from: http://www.cancer.org/cancer/bladdercancer/detailedguide/bladder-cancer-staging. Accessed August 7, 2015.

48. Rouprêt M, Babjuk M, Compérat E, et al. European guidelines on upper tract urothelial carcinomas: 2013 update. Eur Urol. 2013;63(6): 1059-1071

49. Khanna C, Lindblad-Toh K, Vail D, et al. The dog as a cancer model. Nat Biotechnol. 2006;24(9):1065-1066.

50. Mayo Clinic [webpage on the Internet]. Diseases and Conditions: Bladder Cancer. 2014. Available from: http://www.mayoclinic.org/ diseases-conditions/bladder-cancer/basics/risk-factors/con-20027606. Accessed August 12, 2014.

51. Solsona E, Iborra I, Ricos JV, Monros JL, Casanova J, Dumont R. Effectiveness of a single immediate mitomycin $\mathrm{C}$ instillation in patients with low risk superficial bladder cancer: short and long-term followup. J Urol. 1999;161(4):1120-1123.

52. Ali-el-Dein B, Nabeeh A, el-Baz M, Shamaa S, Ashamallah A. Singledose versus multiple instillations of epirubicin as prophylaxis for recurrence after transurethral resection of pTa and pT1 transitional-cell bladder tumours: a prospective, randomized controlled study. Br J Urol. 1997;79(5):731-735.

53. Lamm DL, Blumenstein BA, Crawford ED, et al. A randomized trial of intravesical doxorubicin and immunotherapy with bacille CalmetteGuerin for transitional-cell carcinoma of the bladder. N Engl J Med. 1991;325(17):1205-1209.

54. Herr HW, Schwalb DM, Zhang ZF, et al. Intravesical bacillus CalmetteGuerin therapy prevents tumor progression and death from superficial bladder cancer: ten-year follow-up of a prospective randomized trial. J Clin Oncol. 1995;13(6):1404-1408.

55. Kawai K, Miyazaki J, Joraku A, Nishiyama H, Akaza H. Bacillus Calmette-Guerin (BCG) immunotherapy for bladder cancer: current understanding and perspectives on engineered $\mathrm{BCG}$ vaccine. Cancer Sci. 2013;104(1):22-27.

56. Lamm DL. BCG in perspective: advances in the treatment of superficial bladder cancer. Eur Urol. 1995;27(suppl 1):2-8.

57. Chemotherapy for Bladder Cancer [webpage on the Internet]. Treatment for Bladder Cancer. 2015. Available from: http:/www.cancer.org/cancer/ bladdercancer/detailedguide/bladder-cancer-treating-chemotherapy. Accessed 12 August, 2015.

58. Kanatani A, Nakagawa T, Kawai T, et al. Adjuvant chemotherapy is possibly beneficial for locally advanced or node-positive bladder cancer. Clin Genitourin Cancer. 2014;13(2):e107-e112.

59. Carballido EM, Rosenberg JE. Optimal treatment for metastatic bladder cancer. Curr Oncol Rep. 2014;16(9):404.

60. Dragan YP, Sargent L, Xu YD, Xu YH, Pitot HC. The initiation-promotion-progression model of rat hepatocarcinogenesis. Exp Biol Med. 1993;202(1):16-24.

61. Hennings H, Glick AB, Greenhalgh DA, et al. Critical aspects of initiation, promotion, and progression in multistage epidermal carcinogenesis. Exp Biol Med. 1993;202(1):1-8.

62. Smith G, Carey FA, Beattie J, et al. Mutations in APC, Kirsten-ras, and p53 - alternative genetic pathways to colorectal cancer. Proc Natl Acad Sci U S A. 2002;99(14):9433-9438.

63. McCullough S, Hu Y, Li R. BRCA1 in initiation, invasion, and metastasis of breast cancer: a perspective from the tumor microenvironment. In: Mansel R, Fodstad O, Jiang W, editors. Metastasis of Breast Cancer. Vol. 11. Netherlands: Springer; 2007:31-46.

64. McConkey DJ, Lee S, Choi W, et al. Molecular genetics of bladder cancer: emerging mechanisms of tumor initiation and progression. Urol Oncol. 2010;28(4):429-440.

65. Network TC. Comprehensive molecular characterization of urothelial bladder carcinoma. Nature. 2014;507(7492):315-322.
66. Mitra AP, Datar RH, Cote RJ. Molecular pathways in invasive bladder cancer: new insights into mechanisms, progression, and target identification. J Clin Oncol. 2006;24(35):5552-5564.

67. Sherr CJ, McCormick F. The RB and p53 pathways in cancer. Cancer Cell. 2002;2(2):103-112.

68. Aprelikova O, Xiong Y, Liu ET. Both p16 and p21 families of cyclindependent kinase (CDK) inhibitors block the phosphorylation of cyclin-dependent kinases by the CDK-activating kinase. J Biol Chem. 1995;270(31):18195-18197.

69. Hollstein M, Sidransky D, Vogelstein B, Harris CC. p53 mutations in human cancers. Science. 1991;253(5015):49-53

70. Esrig D, Elmajian D, Groshen S, etal. Accumulation of nuclearp53 and tumor progression in bladder cancer. N Engl J Med. 1994;331(19):1259-1264.

71. Cooper MJ, Haluschak JJ, Johnson D, et al. p53 mutations in bladder carcinoma cell lines. Oncol Res. 1994;6(12):569-579.

72. Zhu HB, Yang K, Xie YQ, Lin YW, Mao QQ, Xie LP. Silencing of mutant $\mathrm{p} 53$ by siRNA induces cell cycle arrest and apoptosis in human bladder cancer cells. World J Surg Oncol. 2013;11:22.

73. Chatterjee SJ, Datar R, Youssefzadeh D, et al. Combined effects of p53, $\mathrm{p} 21$, and $\mathrm{pRb}$ expression in the progression of bladder transitional cell carcinoma. J Clin Oncol. 2004;22(6):1007-1013.

74. El-Deiry WS, Tokino T, Velculescu VE, et al. WAF1, a potential mediator of p53 tumor suppression. Cell. 1993;75(4):817-825.

75. Ahmad I, Sansom OJ, Leung HY. Exploring molecular genetics of bladder cancer: lessons learned from mouse models. Dis Model Mech. 2012;5(3):323-332.

76. Hinata N, Shirakawa T, Zhang Z, et al. Radiation induces p53-dependent cell apoptosis in bladder cancer cells with wild-type- p53 but not in p53-mutated bladder cancer cells. Urol Res. 2003;31(6):387-396.

77. Pavletich NP, Chambers KA, Pabo CO. The DNA-binding domain of p53 contains the four conserved regions and the major mutation hot spots. Genes Dev. 1993;7(12B):2556-2564.

78. Harms KL, Chen $X$. The functional domains in $\mathrm{p} 53$ family proteins exhibit both common and distinct properties. Cell Death Differ. 2006; 13(6):890-897.

79. Teufel DP, Freund SM, Bycroft M, Fersht AR. Four domains of p300 each bind tightly to a sequence spanning both transactivation subdomains of p53. Proc Natl Acad Sci U S A. 2007;104(17):7009-7014.

80. Mizuarai S, Yamanaka K, Kotani H. Mutant p53 induces the GEF-H1 oncogene, a guanine nucleotide exchange factor-H1 for RhoA, resulting in accelerated cell proliferation in tumor cells. Cancer Res. 2006; 66(12):6319-6326.

81. Piantino CB, Reis ST, Viana NI, et al. Prima-1 induces apoptosis in bladder cancer cell lines by activating p53. Clinics (Sao Paulo). 2013;68: 297-303.

82. Wang S, Konorev EA, Kotamraju S, Joseph J, Kalivendi S, Kalyanaraman B. Doxorubicin induces apoptosis in normal and tumor cells via distinctly different mechanisms: intermediacy of H2O2- and p53-dependent pathways. J Biol Chem. 2004;279(24):25535-25543.

83. Zhu X, Belmont HJ, Price-Schiavi S, et al. Visualization of p53264-272/ HLA-A* 0201 complexes naturally presented on tumor cell surface by a multimeric soluble single-chain $\mathrm{T}$ cell receptor. $J$ Immunol. 2006;176(5):3223-3232.

84. Fishman MN, Thompson JA, Pennock GK, et al. Phase I trial of ALT-801, an interleukin-2/T-cell receptor fusion protein targeting p53 (aa264-272)/HLA-A* 0201 complex, in patients with advanced malignancies. Clin Cancer Res. 2011;17(24):7765-7775.

85. Stadler WM, Lerner SP, Groshen S, et al. Phase III study of molecularly targeted adjuvant therapy in locally advanced urothelial cancer of the bladder based on p53 status. J Clin Oncol. 2011;29(25):3443-3449.

86. Hanahan D, Weinberg Robert A. Hallmarks of cancer: the next generation. Cell. 2011;144(5):646-674.

87. van Rhijn BW, van der Kwast TH, Vis AN, et al. FGFR3 and P53 characterize alternative genetic pathways in the pathogenesis of urothelial cell carcinoma. Cancer Res. 2004;64(6):1911-1914.

88. Jebar AH, Hurst CD, Tomlinson DC, Johnston C, Taylor CF, Knowles MA. FGFR3 and Ras gene mutations are mutually exclusive genetic events in urothelial cell carcinoma. Oncogene. 2005;24(33): 5218-5225. 
89. Sun $\mathrm{CH}$, Chang YH, Pan CC. Activation of the PI3K/Akt/mTOR pathway correlates with tumour progression and reduced survival in patients with urothelial carcinoma of the urinary bladder. Histopathology. 2011;58(7):1054-1063.

90. van Rhijn BW, Lurkin I, Radvanyi F, Kirkels WJ, van der Kwast TH, Zwarthoff EC. The fibroblast growth factor receptor 3 (FGFR3) mutation is a strong indicator of superficial bladder cancer with low recurrence rate. Cancer Res. 2001;61(4):1265-1268.

91. Mansour A, Abdulreheem M, Elsherbeeny M, et al. EGFR expression predicts recurrence in patients undergoing adjuvant chemotherapy for advanced bladder cancer. Cancer Res. 2014;74(19 suppl):904.

92. Zhao J, Xu W, Zhang Z, et al. Prognostic role of HER2 expression in bladder cancer: a systematic review and meta-analysis. Int Urol Nephrol. 2015;47(1):87-94.

93. Kopparapu PK, Boorjian SA, Robinson BD, et al. Expression of VEGF and its receptors VEGFR1/VEGFR2 is associated with invasiveness of bladder cancer. Anticancer Res. 2013;33(6):2381-2390.

94. Tsai YC, Yeh CH, Tzen KY, et al. Targeting epidermal growth factor receptor/human epidermal growth factor receptor 2 signalling pathway by a dual receptor tyrosine kinase inhibitor afatinib for radiosensitisation in murine bladder carcinoma. Eur J Cancer. 2013; 49(6):1458-1466.

95. Escudier B, Pluzanska A, Koralewski P, et al. Bevacizumab plus interferon alfa-2a for treatment of metastatic renal cell carcinoma: a randomised, double-blind phase III trial. Lancet. 2007;370(9605): 2103-2111.

96. Knowles MA, Platt FM, Ross RL, Hurst CD. Phosphatidylinositol 3-kinase (PI3K) pathway activation in bladder cancer. Cancer Metastasis Rev. 2009;28(3-4):305-316.

97. Cantley LC, Neel BG. New insights into tumor suppression: PTEN suppresses tumor formation by restraining the phosphoinositide 3-kinase/AKT pathway. Proc Natl Acad Sci U S A. 1999;96(8): 4240-4245.

98. Puzio-Kuter AM, Castillo-Martin M, Kinkade CW, et al. Inactivation of p53 and Pten promotes invasive bladder cancer. Genes Dev. 2009;23(6):675-680.

99. Carayol N, Vakana E, Sassano A, et al. Critical roles for mTORC2-and rapamycin-insensitive mTORC1-complexes in growth and survival of BCR-ABL-expressing leukemic cells. Proc Natl Acad Sci U S A 2010;107(28):12469-12474.

100. Zeng Z, Sarbassov DD, Samudio IJ, et al. Rapamycin derivatives reduce mTORC2 signaling and inhibit AKT activation in AML. Blood. 2007;109(8):3509-3512.

101. Streeter EH, Harris AL. Angiogenesis in bladder cancer - prognostic marker and target for future therapy. Surg Oncol. 2002;11(1-2): $85-100$.

102. Jones A, Fujiyama C, Blanche C, et al. Relation of vascular endothelial growth factor production to expression and regulation of hypoxiainducible factor- 1 alpha and hypoxia-inducible factor- 2 alpha in human bladder tumors and cell lines. Clin Cancer Res. 2001;7(5): $1263-1272$

103. De Luca A, Carotenuto A, Rachiglio A, et al. The role of the EGFR signaling in tumor microenvironment. $J$ Cell Physiol. 2008; 214(3):559-567.

104. Gravas S, Bosinakou I, Kehayas P, Giannopoulos A. Urinary basic fibroblast growth factor in bladder cancer patients. Histopathological correlation and clinical potential. Urol Int. 2004;73(2):173-177.

105. Stachowiak MK, Moffett J, Joy A, Puchacz E, Florkiewicz R, Stachowiak EK. Regulation of bFGF gene expression and subcellular distribution of bFGF protein in adrenal medullary cells. $J$ Cell Biol. 1994;127(1):203-223.

106. Li A, Dubey S, Varney ML, Dave BJ, Singh RK. IL-8 directly enhanced endothelial cell survival, proliferation, and matrix metalloproteinases production and regulated angiogenesis. J Immunol. 2003;170(6):3369-3376

107. Zhu Z, Shen Z, Xu C. Inflammatory pathways as promising targets to increase chemotherapy response in bladder cancer. Mediators Inflamm. 2012;2012:528690.
108. Lamm DL. Bacillus Calmette-Guerin immunotherapy for bladder cancer. J Urol. 1985;134(1):40-47.

109. Thompson RH, Dong H, Lohse CM, et al. PD-1 is expressed by tumor-infiltrating immune cells and is associated with poor outcome for patients with renal cell carcinoma. Clin Cancer Res. 2007;13(6):1757-1761.

110. Najjar YG, Kirkwood JM. Pembrolizumab: pharmacology and therapeutics review. Hematologic. 2015;17-19.

111. Lutzky J, Antonia SJ, Blake-Haskins A, et al. A phase 1 study of MEDI4736, an anti-PD-L1 antibody, in patients with advanced solid tumors. Paper presented at: ASCO Annual Meeting Proceedings; 2014

112. Cho DC, Sosman JA, Sznol M, et al. Clinical activity, safety, and biomarkers of MPDL3280A, an engineered PD-L1 antibody in patients with metastatic renal cell carcinoma (mRCC). J Clin Oncol. 2013;31:a4505

113. Peggs KS, Quezada SA, Korman AJ, Allison JP. Principles and use of anti-CTLA4 antibody in human cancer immunotherapy. Curr Opin Immunol. 2006;18(2):206-213.

114. Ribas A, Kefford R, Marshall MA, et al. Phase III randomized clinical trial comparing tremelimumab with standard-of-care chemotherapy in patients with advanced melanoma. J Clin Oncol. 2013;31(5): 616-622.

115. Hodi FS, O'Day SJ, McDermott DF, et al. Improved survival with ipilimumab in patients with metastatic melanoma. $N$ Engl $J$ Med. 2010;363(8):711-723.

116. Prieto PA, Yang JC, Sherry RM, et al. CTLA-4 blockade with ipilimumab: long-term follow-up of 177 patients with metastatic melanoma. Clin Cancer Res. 2012;18(7):2039-2047.

117. Yang JC, Hughes M, Kammula U, et al. Ipilimumab (anti-CTLA4 antibody) causes regression of metastatic renal cell cancer associated with enteritis and hypophysitis. J Immunother. 2007; 30(8):825.

118. Wong HC, Jeng EK, Rhode PR. The IL-15-based superagonist ALT803 promotes the antigen-independent conversion of memory CD8+ $\mathrm{T}$ cells into innate-like effector cells with antitumor activity. Oncoimmunology. 2013;2(11):e26442.

119. Tosello A-C, Mary F, Amiot M, Bernard A, Mary D. Activation of $\mathrm{T}$ cells via CD55: recruitment of early components of the CD3TCR pathway is required for IL-2 secretion. J Inflamm. 1997;48(1): $13-27$.

120. Ciocca DR, Calderwood SK. Heat shock proteins in cancer: diagnostic, prognostic, predictive, and treatment implications. Cell Stress Chaperones. 2005;10(2):86.

121. Schmitt E, Gehrmann M, Brunet M, Multhoff G, Garrido C. Intracellular and extracellular functions of heat shock proteins: repercussions in cancer therapy. J Leukoc Biol. 2007;81(1):15-27.

122. da Rocha Dias S, Friedlos F, Light Y, Springer C, Workman P, Marais R. Activated B-RAF is an Hsp90 client protein that is targeted by the anticancer drug 17-allylamino-17-demethoxygeldanamycin. Cancer Res. 2005;65(23):10686-10691.

123. O'Callaghan-Sunol C, Gabai VL, Sherman MY. Hsp27 modulates p53 signaling and suppresses cellular senescence. Cancer Res. 2007; 67(24):11779-11788.

124. Proia DA, Sang J, He S, et al. Synergistic activity of the Hsp90 inhibitor ganetespib with taxanes in non-small cell lung cancer models. Invest New Drugs. 2012;30(6):2201-2209.

125. Ying W, Du Z, Sun L, et al. Ganetespib, a unique triazolone-containing Hsp90 inhibitor, exhibits potent antitumor activity and a superior safety profile for cancer therapy. Mol Cancer Ther. 2012;11(2): 475-484.

126. Kamada M, So A, Muramaki M, Rocchi P, Beraldi E, Gleave M. Hsp27 knockdown using nucleotide-based therapies inhibit tumor growth and enhance chemotherapy in human bladder cancer cells Mol Cancer Ther. 2007;6(1):299-308.

127. Maruyama R, Toyooka S, Toyooka KO, et al. Aberrant promoter methylation profile of bladder cancer and its relationship to clinicopathological features. Cancer Res. 2001;61(24):8659-8663. 
128. Bertino EM, Otterson GA. Romidepsin: a novel histone deacetylase inhibitor for cancer. Expert Opin Investig Drugs. 2011;20(8): 1151-1158.

129. Suzuki T, Tanaka R, Hamada S, Nakagawa H, Miyata N. Design, synthesis, inhibitory activity, and binding mode study of novel DNA methyltransferase 1 inhibitors. Bioorg Med Chem Lett. 2010;20(3): 1124-1127.

130. Li DR, Zhang H, Peek E, et al. Synergy of histone-deacetylase inhibitor AR-42 with cisplatin in bladder cancer. J Urol. 2015; 194(2):547-555.

131. Chen X, Scapa J, Liu D, Godbey W. Cancer-specific promoters for expression-targeted gene therapy: ran, brms1, and mcm5.J Gene Med. 2016;18(7):89-101.

132. Kalluri R, Neilson EG. Epithelial-mesenchymal transition and its implications for fibrosis. J Clin Invest. 2003;112(12):1776-1784.

133. Maschler S, Wirl G, Spring H, et al. Tumor cell invasiveness correlates with changes in integrin expression and localization. Oncogene. 2005;24(12):2032-2041.

134. Zhu J, Pan X, Zhang Z, Gao J, Zhang L, Chen J. Downregulation of integrin-linked kinase inhibits epithelial-to-mesenchymal transition and metastasis in bladder cancer cells. Cell Signal. 2012; 24(6):1323-1332.

135. Sachs MD, Rauen KA, Ramamurthy $M$, et al. Integrin $\alpha \mathrm{v}$ and coxsackie adenovirus receptor expression in clinical bladder cancer. Urology. 2002;60(3):531-536.

136. Tsuji S, Chen X, Hancock B, et al. Preclinical evaluation of VAX-IP, a novel bacterial minicell-based biopharmaceutical for nonmuscle invasive bladder cancer. Mol Ther Oncolytics. 2016;3:16004.

137. Wang H, Cai Z, Yang F, et al. Enhanced antitumor efficacy of integrintargeted oncolytic adenovirus AxdAdB3-F/RGD on bladder cancer. Urology. 2014;83(2):508.e13-508.e19.

138. van der Horst G, Bos L, van der Mark M, et al. Targeting of alpha-V integrins reduces malignancy of bladder carcinoma. PLoS One. 2014;9(9):e108464.

139. Mitsuzuka K, Handa K, Satoh M, Arai Y, Hakomori S. A specific microdomain ("glycosynapse 3") controls phenotypic conversion and reversion of bladder cancer cells through GM3-mediated interaction of $\alpha 3 \beta 1$ integrin with CD9. J Biol Chem. 2005;280(42): 35545-35553.

140. Li C, Yang Z, Du Y, et al. BCMab1, a monoclonal antibody against aberrantly glycosylated integrin $\alpha 3 \beta 1$, has potent antitumor activity of bladder cancer in vivo. Clin Cancer Res. 2014;20(15):4001-4013.

141. Mohammed SI, Knapp DW, Bostwick DG, et al. Expression of cyclooxygenase-2 (COX-2) in human invasive transitional cell carcinoma (TCC) of the urinary bladder. Cancer Res. 1999;59(22):5647-5650.

142. Rathore K, Alexander M, Cekanova M. Piroxicam inhibits Masitinibinduced cyclooxygenase 2 expression in oral squamous cell carcinoma cells in vitro. Transl Res. 2014;164(2):158-168.

143. Thanan R, Murata M, Ma N, et al. Nuclear localization of COX-2 in relation to the expression of stemness markers in urinary bladder cancer. Mediators Inflamm. 2012;2012:165879.

144. Yu Z, Pestell TG, Lisanti MP, Pestell RG. Cancer stem cells. Int J Biochem Cell Biol. 2012;44(12):2144-2151.

145. Chan KS, Espinosa I, Chao M, et al. Identification, molecular characterization, clinical prognosis, and therapeutic targeting of human bladder tumor-initiating cells. Proc Natl Acad Sci US A. 2009;106(33): 14016-14021.

146. Marotta LL, Almendro V, Marusyk A, et al. The JAK2/STAT3 signaling pathway is required for growth of CD44+ CD24-stem cell-like breast cancer cells in human tumors. J Clin Invest. 2011; 121(7):2723.

147. Damrauer JS, Hoadley KA, Chism DD, et al. Intrinsic subtypes of high-grade bladder cancer reflect the hallmarks of breast cancer biology. Proc Natl Acad Sci U S A. 2014;111(8):3110-3115.

148. Li Y, Rogoff HA, Keates S, et al. Suppression of cancer relapse and metastasis by inhibiting cancer stemness. Proc Natl Acad Sci U S A. 2015;112(6):1839-1844.
149. Kurtova AV, Xiao J, Mo Q, et al. Blocking PGE2-induced tumour repopulation abrogates bladder cancer chemoresistance. Nature. 2015;517(7533):209-213.

150. Sonpavde G, Jones BS, Bellmunt J, Choueiri TK, Sternberg CN. Future directions and targeted therapies in bladder cancer. Hematol Oncol Clin North Am. 2015;29(2):361-376,x.

151. Ding J, Xu D, Pan C, et al. Current animal models of bladder cancer: awareness of translatability (review). Exp Ther Med. 2014; 8(3):691-699.

152. Ertürk E, Cohen S, Price J, Bryan GT. Pathogenesis, histology, and transplantability of urinary bladder carcinomas induced in albino rats by oral administration of N-[4-(5-nitro-2-furyl)-2-thiazolyl] formamide. Cancer Res. 1969;29(12):2219-2228.

153. Becci PJ, Thompson HJ, Strum JM, Brown CC, Sporn MB, Moon RC. N-butyl-N-(4-hydroxybutyl) nitrosamine-induced urinary bladder cancer in $\mathrm{C} 57 \mathrm{BL} / 6 \times \mathrm{DBA} / 2 \mathrm{~F} 1$ mice as a useful model for study of chemoprevention of cancer with retinoids. Cancer Res. 1981; 41(3):927-932.

154. Oliveira P, Palmeira C, Lourenço L, Lopez C. Evaluation of DNA content in preneoplastic changes of mouse urinary bladder induced by N-butyl-N-(4-hydroxybutyl) nitrosamine. J Exp Clin Cancer Res. 2005;24(4):609.

155. Lu Y, Liu P, Wen W, et al. Cross-species comparison of orthologous gene expression in human bladder cancer and carcinogen-induced rodent models. Am J Transl Res. 2010;3(1):8-27.

156. Oyasu R. Epithelial tumours of the lower urinary tract in humans and rodents. Food Chem Toxicol. 1995;33(9):747-755.

157. Zhang ZT, Pak J, Huang HY, et al. Role of Ha-ras activation in superficial papillary pathway of urothelial tumor formation. Oncogene. 2001;20(16):1973-1980.

158. He F, Mo L, Zheng XY, et al. Deficiency of $\mathrm{pRb}$ family proteins and p53 in invasive urothelial tumorigenesis. Cancer Res. 2009; 69(24):9413-9421.

159. Cheng J, Huang H, Zhang ZT, et al. Overexpression of epidermal growth factor receptor in urothelium elicits urothelial hyperplasia and promotes bladder tumor growth. Cancer Res. 2002;62(14): 4157-4163.

160. Zhang N, Li D, Shao J, Wang X. Animal models for bladder cancer: the model establishment and evaluation (Review). Oncol Lett. 2015; 9(4):1515-1519.

161. Teicher BA. Tumor models for efficacy determination. Mol Cancer Ther. 2006;5(10):2435-2443.

162. Eklund L, Bry M, Alitalo K. Mouse models for studying angiogenesis and lymphangiogenesis in cancer. Mol Oncol. 2013;7(2): 259-282.

163. Bibby M. Orthotopic models of cancer for preclinical drug evaluation: advantages and disadvantages. Eur J Cancer. 2004;40(6): 852-857.

164. Lodillinsky C, Rodriguez V, Vauthay L, Sandes E, Casabé A, Eiján AM. Novel invasive orthotopic bladder cancer model with high cathepsin B activity resembling human bladder cancer. J Urol. 2009;182(2):749-755.

165. Cekanova M, Rathore K. Animal models and therapeutic molecular targets of cancer: utility and limitations. Drug Des Devel Ther. 2014; 8:1911-1921.

166. Mak IW, Evaniew N, Ghert M. Lost in translation: animal models and clinical trials in cancer treatment. Am J Transl Res. 2014; 6(2): 114 .

167. Norris AM, Laing EJ, Valli VE, et al. Canine bladder and urethral tumors: a retrospective study of 115 cases (1980-1985). J Vet Intern Med. 1992;6(3):145-153.

168. Mutsaers AJ, Widmer WR, Knapp DW. Canine transitional cell carcinoma. J Vet Intern Med. 2003;17(2):136-144.

169. Glickman LT, Schofer FS, McKee LJ, Reif JS, Goldschmidt MH. Epidemiologic study of insecticide exposures, obesity, and risk of bladder cancer in household dogs. J Toxicol Environ Health. 1989; 28(4):407-414. 
170. Weller R, Wolf A, Oyejide A. Transitional cell carcinoma of the bladder associated with cyclophosphamide therapy in a dog. J Amer Anim Hosp Assoc. 1979;5:733-736.

171. Bryan JN, Keeler MR, Henry CJ, Bryan ME, Hahn AW, Caldwell CW. A population study of neutering status as a risk factor for canine prostate cancer. Prostate. 2007;67(11):1174-1181.

172. Withrow SJ, Vail DM, Page R. Withrow and MacEwen's Small Animal Clinical Oncology. Elsevier Health Sciences; 2013.

173. Knapp DW, Glickman NW, DeNicola DB, Bonney PL, Lin TL, Glickman LT. Naturally-occurring canine transitional cell carcinoma of the urinary bladder. A relevant model of human invasive bladder cancer. Paper presented at: Urologic Oncology: Seminars and Original Investigations; 2000.

174. Okajima E, Hiramatsu T, Hirao K, et al. Urinary bladder tumors induced by N-butyl-N-(4-hydroxybutyl) nitrosamine in dogs. Cancer Res. 1981;41(5):1958-1966.

175. Patronek GJ, Waters DJ, Glickman LT. Comparative longevity of pet dogs and humans: implications for gerontology research. J Gerontol A. 1997;52(3):B171-B178.

176. Herr H, Shipley W, Bajorin D. Cancer of the bladder. Cancer: Principles and Practice of Oncology. 6th ed. Philadelphia, PA: Lippincott Williams \& Wilkins; 2001:1396-1418.

177. Knapp DW, Ramos-Vara JA, Moore GE, Dhawan D, Bonney PL, Young KE. Urinary bladder cancer in dogs, a naturally occurring model for cancer biology and drug development. ILAR J. 2014;55(1):100-118.

178. Dill AL, Eberlin LS, Costa AB, et al. Multivariate statistical identification of human bladder carcinomas using ambient ionization imaging mass spectrometry. Chem-A Eur J. 2011;17(10):2897-2902.

179. Cekanova M, Uddin MJ, Bartges JW, et al. Molecular imaging of cyclooxygenase-2 in canine transitional cell carcinomas in vitro and in vivo. Cancer Prev Res. 2013;6(5):466-476.

180. Burger M, Catto JW, Dalbagni G, et al. Epidemiology and risk factors of urothelial bladder cancer. Eur Urol. 2013;63(2):234-241.

181. Meuten D. Tumors of the urinary system. In: Meuten D, editor. Tumors in Domestic Animals. 4th ed. Hoboken, NJ: John Wiley \& Sons Inc.; 2002:509-546.

182. Owen LN. TNM Classification of Tumours in Domestic Animals. Geneva: World Health Organization; 1980.

183. Walker M, Breider M. Intraoperative radiotherapy of canine bladder cancer. Veter Radiol. 1987;28(6):200-204.

184. Knapp DW, Richardson RC, Bottoms GD, Teclaw R, Chan TC. Phase I trial of piroxicam in 62 dogs bearing naturally occurring tumors. Cancer Chemother Pharmacol. 1992;29(3):214-218.

185. Knapp DW, Glickman NW, Widmer WR, et al. Cisplatin versus cisplatin combined with piroxicam in a canine model of human invasive urinary bladder cancer. Cancer Chemother Pharmacol. 2000; 46(3):221-226

186. Knapp D, Schmidt B, Widmer W. Preliminary results of carboplatin/ piroxicam therapy in canine transitional cell carcinoma. Paper presented at: Proceedings 17th Veterinary Cancer Society - American College of Veterinary Radiology Conference; 1997; Chicago, IL.

187. Dhawan D, Craig BA, Cheng L, et al. Effects of short-term celecoxib treatment in patients with invasive transitional cell carcinoma of the urinary bladder. Mol Cancer Ther. 2010;9(5):1371-1377.

188. Low PS, Henne WA, Doorneweerd DD. Discovery and development of folic-acid-based receptor targeting for imaging and therapy of cancer and inflammatory diseases. Acc Chem Res. 2008;41(1):120-129.

189. Dhawan D, Ramos-Vara JA, Naughton JF, et al. Targeting folate receptors to treat invasive urinary bladder cancer. Cancer Res. 2013 73(2):875-884.

190. Hahn NM, Bonney PL, Dhawan D, et al. Subcutaneous 5-azacitidine treatment of naturally occurring canine urothelial carcinoma: a novel epigenetic approach to human urothelial carcinoma drug development. J Urol. 2012;187(1):302-309.

191. Lien K, Georgsdottir S, Sivanathan L, Chan K, Emmenegger U. Low-dose metronomic chemotherapy: a systematic literature analysis. Eur J Cancer. 2013;49(16):3387-3395.
192. Schrempp DR, Childress MO, Stewart JC, et al. Metronomic administration of chlorambucil for treatment of dogs with urinary bladder transitional cell carcinoma. J Am Vet Med Assoc. 2013;242(11): 1534-1538.

193. Cekanova M, Uddin MJ, Legendre AM, et al. Single-dose safety and pharmacokinetic evaluation of fluorocoxib A: pilot study of novel cyclooxygenase-2-targeted optical imaging agent in a canine model. J Biomed Opt. 2012;17(11):116002-116002.

194. Rathore K, Cekanova M. Animal model of naturally occurring bladder cancer: characterization of four new canine transitional cell carcinoma cell lines. BMC Cancer. 2014;14(1):465.

195. Dhawan D, Ramos-Vara JA, Stewart JC, Zheng R, Knapp DW. Canine invasive transitional cell carcinoma cell lines: in vitro tools to complement a relevant animal model of invasive urinary bladder cancer. Urol Oncol. 2009;27(3):284-292.

196. Ramlau R, Gorbunova V, Ciuleanu TE, et al. Aflibercept and docetaxel versus docetaxel alone after platinum failure in patients with advanced or metastatic non-small-cell lung cancer: a randomized, controlled phase III trial. J Clin Oncol. 2012;30(29):3640-3647.

197. Yakes FM, Chen J, Tan J, et al. Cabozantinib (XL184), a novel MET and VEGFR2 inhibitor, simultaneously suppresses metastasis, angiogenesis, and tumor growth. Mol Cancer Ther. 2011;10(12): 2298-2308.

198. Sleijfer S, Ray-Coquard I, Papai Z, et al. Pazopanib, a multikinase angiogenesis inhibitor, in patients with relapsed or refractory advanced soft tissue sarcoma: a phase II study from the European Organisation for Research and Treatment of Cancer-Soft Tissue and Bone Sarcoma Group (EORTC study 62043). J Clin Oncol. 2009;27(19): 3126-3132.

199. Jordan VC. Tamoxifen as the first successful targeted therapy in cancer: the gift that kept on giving. Breast Cancer Management. 2014; 3(4):321-326.

200. Wen PY, Yung W, Mellinghoff IK, et al. Phase II trial of the phosphatidyinositol-3 kinase (PI3K) inhibitor buparlisib (BKM120) in recurrent glioblastoma. Paper presented at: ASCO Annual Meeting Proceedings; Chicago, IL, USA; 2014.

201. Angevin E, Grunwald V, Ravaud A, et al. A phase II study of dovitinib (TKI258), an FGFR-and VEGFR-inhibitor, in patients with advanced or metastatic renal cell cancer (mRCC). Paper presented at: ASCO Meet Abstr; 2011.

202. Bendell JC, Papadopoulos K, Jones SF, et al. Abstract B243: a phase I dose-escalation study of MEK inhibitor MEK162 (ARRY-438162) in patients with advanced solid tumors. Mol Cancer Ther. 2011; 10(11 suppl):B243-B243.

203. Nordstrom JL, Gorlatov S, Zhang W, et al. Anti-tumor activity and toxicokinetics analysis of MGAH22, an anti-HER2 monoclonal antibody with enhanced Fcg receptor binding properties. Breast Cancer Res. 2011;13:R123.

204. Davies B, Thomason A, Ellston R, et al. 457 Preclinical pharmacology of AZD5312, a generation 2.5 antisense oligonucletotide targeting the androgen receptor with differentiated activity from enzalutamide. Eur J Cancer. 2014;50:150.

205. Kirchner GI, Meier-Wiedenbach I, Manns MP. Clinical pharmacokinetics of everolimus. Clin Pharmacokinet. 2004;43(2):83-95.

206. Hidalgo M, Rowinsky EK. The rapamycin-sensitive signal transduction pathway as a target for cancer therapy. Oncogene. 2000;19(56): 6680-6686.

207. Desai N, D’Cruz O, Trieu V. Combination regimens of nab-rapamycin (ABI-009) effective against MDA-MB-231 breast-tumor xenografts Cancer Res. 2009:9-13. Paper presented at the thirty-Second Annual CTRC-AACR San Antonio Breast Cancer Symposium - Dec 10-13, 2009; San Antonio, TX, Cancer Research, 2009; 69(24) Supplement.

208. Steinberg GD, Shore N, Karsh L, et al. A Phase I/II study of vesigenurtacel-1 (hs-410) or placebo in combination with Bacillus Calmette-Guérin (BCG) in patients with non-muscle invasive bladder cancer (NMIBC). J ImmunoTherapy Cancer. 2014; 2(suppl 3):81. 
209. Xu W, Jones M, Liu B, et al. Efficacy and mechanism-of-action of a novel superagonist interleukin-15: interleukin-15 receptor alphaSu/Fc fusion complex in syngeneic murine models of multiple myeloma. Cancer Res. 2013;73(10):3075-3086.

210. Ribas A, Hanson DC, Noe DA, et al. Tremelimumab (CP-675,206), a cytotoxic $\mathrm{T}$ lymphocyte-associated antigen 4 blocking monoclonal antibody in clinical development for patients with cancer. Oncologist. 2007;12(7):873-883.

211. Yang P, Coleman J, Li Y, et al. SLITRK6, the target of a novel antibody drug conjugate AGS15E, is expressed in bladder and other cancers. Paper presented at: CANCER RESEARCH; 2013.

212. Kozłowska A, Mackiewicz J, Mackiewicz A. Therapeutic gene modified cell based cancer vaccines. Gene. 2013;525(2):200-207.

213. Boni V, Rixe O, Rasco D, et al. Abstract A73: a phase I first-inhuman (FIH) study of SAR566658, an anti CA6-antibody drug conjugate (ADC), in patients (Pts) with CA6-positive advanced solid tumors (STs)(NCT01156870). Mol Cancer Ther. 2013;12(11 suppl): A73-A73.

214. Ferrajoli A, Lee BN, Schlette EJ, et al. Lenalidomide induces complete and partial remissions in patients with relapsed and refractory chronic lymphocytic leukemia. Blood. 2008;111(11):5291-5297.

215. Goel S, Mita AC, Mita M, et al. A phase I study of eribulin mesylate (E7389), a mechanistically novel inhibitor of microtubule dynamics, in patients with advanced solid malignancies. Clin Cancer Res. 2009;15(12):4207-4212.
216. Miele E, Spinelli GP, Miele E, Tomao F, Tomao S. Albumin-bound formulation of paclitaxel (Abraxane ${ }^{\mathbb{R}} \mathrm{ABI}-007$ ) in the treatment of breast cancer. Int J Nanomedicine. 2009;4:99.

217. Roche M, Kyriakou H, Seiden M. Drug evaluation: tesetaxel - an oral semisynthetic taxane derivative. Curr Opin Invest Drugs. 2006; 7(12):1092-1099.

218. Lattanzio R, Ghasemi R, Brancati F, et al. Membranous Nectin-4 expression is a risk factor for distant relapse of T1-T2, N0 luminal-A early breast cancer. Oncogenesis. 2014;3(9):e118.

219. Hanada M, Mizuno S, Fukushima A, Saito Y, Noguchi T, Yamaoka T. A new antitumor agent amrubicin induces cell growth inhibition by stabilizing topoisomerase II-DNA complex. Cancer Sci. 1998;89(11): 1229-1238.

220. Hudson E, Lester JF. Gemcitabine and carboplatin in the treatment of transitional cell carcinoma of the urothelium: a single centre experience and review of the literature. Eur J Cancer Care. 2010; 19(3):324-328.

221. Langleben A, Supko JG, Hotte S, et al. Abstract LB-171: a phase 1 dose escalation study of BBI608, a first-in-class cancer stem cell pathway inhibitor in patients with advanced malignancies. Cancer Res. 2010;70(8 suppl):LB-171.

222. Isakoff S, Overmoyer B, Tung N, et al. A phase II trial of the PARP inhibitor veliparib (ABT888) and temozolomide for metastatic breast cancer. J Clin Oncol. 2010;28(18S):1019.
Drug Design, Development and Therapy

\section{Publish your work in this journal}

Drug Design, Development and Therapy is an international, peerreviewed open-access journal that spans the spectrum of drug design and development through to clinical applications. Clinical outcomes, patient safety, and programs for the development and effective, safe, and sustained use of medicines are the features of the journal, which

\section{Dovepress}

has also been accepted for indexing on PubMed Central. The manuscript management system is completely online and includes a very quick and fair peer-review system, which is all easy to use. Visit http://www.dovepress.com/testimonials.php to read real quotes from published authors. 